IZA DP No. 9991

Internet and Voting in the Web 2.0 Era:

Evidence from a Local Broadband Policy

Samuele Poy

Simone Schüller

June 2016 


\title{
Internet and Voting in the Web 2.0 Era: Evidence from a Local Broadband Policy
}

\author{
Samuele Poy \\ Università Cattolica del Sacro Cuore \\ and Istituto Luigi Sturzo \\ Simone Schüller \\ Ifo Institute, FBK-IRVAPP \\ and $I Z A$
}

Discussion Paper No. 9991

June 2016

IZA

P.O. Box 7240

53072 Bonn

Germany

Phone: +49-228-3894-0

Fax: +49-228-3894-180

E-mail: iza@iza.org

\begin{abstract}
Any opinions expressed here are those of the author(s) and not those of IZA. Research published in this series may include views on policy, but the institute itself takes no institutional policy positions. The IZA research network is committed to the IZA Guiding Principles of Research Integrity.

The Institute for the Study of Labor (IZA) in Bonn is a local and virtual international research center and a place of communication between science, politics and business. IZA is an independent nonprofit organization supported by Deutsche Post Foundation. The center is associated with the University of Bonn and offers a stimulating research environment through its international network, workshops and conferences, data service, project support, research visits and doctoral program. IZA engages in (i) original and internationally competitive research in all fields of labor economics, (ii) development of policy concepts, and (iii) dissemination of research results and concepts to the interested public.
\end{abstract}

IZA Discussion Papers often represent preliminary work and are circulated to encourage discussion. Citation of such a paper should account for its provisional character. A revised version may be available directly from the author. 


\section{ABSTRACT \\ Internet and Voting in the Web 2.0 Era: Evidence from a Local Broadband Policy*}

This article analyzes the impact of a local broadband expansion policy on electoral turnout and party vote share. We exploit a unique policy intervention involving staged broadband infrastructure installation across rural municipalities in the Province of Trento (Italy), thus generating a source of exogenous (spatial and temporal) variation in the provision of advanced broadband technology (ADSL2+). Using a difference-in-differences strategy, we find positive effects of broadband availability on overall electoral turnout at national parliamentary elections. Party vote share analysis shows significant shifts across the ideological spectrum. These shifts, however, are likely transitory rather than persistent. Placebo estimations support a causal interpretation of our results. We provide further evidence that broadband availability is linked to actual adoption in that the broadband policy increased overall Internet and broadband take-up among private households.

JEL Classification: D72, L82, L86

Keywords: broadband internet, political participation, voting behavior, quasi-natural experiment

Corresponding author:

Simone Schüller

Ifo Institute

Leibniz Institute for Economic Research at the University of Munich

Poschingerstraße 5

81679 Munich

Germany

E-mail: schueller.s@ifo.de

\footnotetext{
* We thank Guglielmo Barone, Oliver Falck, Riccardo Ladini, Sonia Marzadro, Paolo Pinotti, Enrico Rettore, Cristiano Vezzoni, and participants of the ifo INT Center Seminar and the ifo Lunchtime Seminar for their excellent comments. We are grateful to Deborah Willow for editorial assistance. Research was mainly carried out during the stay of the authors at the Research Institute for the Evaluation of Public Policies (FBK-IRVAPP) as research fellows. We thank Trentino Network and Telecom Italia for providing us with knowledge and data on the ADSL2+ broadband infrastructure diffusion in the Province of Trento and, especially, Alessandro Zorer. The views expressed are those of the authors and do not necessarily reflect the views of Trentino Network or Telecom Italia.
} 


\section{Introduction}

The impact of new technology on society is the subject of intense debate in the social sciences. Political scientists and economists have thoroughly investigated the impact of new mass media (i.e. radio, TV, Internet) on political participation, economic behavior, and social life (see, e.g., Alterman, 1998; Pratt, 2000; Axford and Huggins, 2001; Lievrouw and Livingstone, 2002). As discussed by Morgan and Shanahan (1992), active and informed citizens are central to the practice of democracy in modern society, and innovations in mass communication have progressively increased the pace and effectiveness of information dissemination and political activation.

In the "digital era," political parties can exploit the Internet to boost both on-line and off-line political participation (see Stanyer, 2005; Bentivegna, 2006; Gibson, 2009; Lilleker and Jackson, 2013; Dutton, 2013; Kindra, Stapenhurst, and Pellizo, 2013). For example, during the 2013 national election campaign in Italy, all major parties had not only a website with multimedia content, but were also active in Web 2.0 applications, that is, they had official YouTube channels, as well as Facebook and Twitter accounts. Although political parties have taken advantage of new opportunities in the world of ICTs, and even though the diffusion of the Internet has considerably increased the speed and lowered the cost of information dissemination, it is not a priori clear whether the Internet increases voters' exposure to political information and what effect, if any, it has on whether and how citizens vote. On the one hand, the significant reduction in the cost of information acquisition may lead to a more informed, and hence more likely to vote, citizenry (see, e.g., Feddersen and Pesendorfer, 1996; Lassen, 2005; Larcinese, 2007). On the other hand, Putnam (1995) hypothesizes that new media increases leisure consumption at the expense of news consumption (on the crowding-out effect of the Internet, see 
also Prior, 2005). Moreover, it is not clear whether the increased variety of information available on the Internet necessarily broadens citizens' viewpoints or whether it might, instead, introduce the risk of polarizing and cementing political positions due type of news consumption being chosen based on previous ideological position (see, e.g., Sunstein, 2007; Sood, Lelkes, and Iyengar, 2015).

Causal empirical evidence of high-speed Internet's impact on political behavior is extremely rare due to the difficulty of addressing endogeneity in broadband access. Since Internet infrastructures are mostly privately funded and hence market-led, telecom providers prefer to roll out in areas with relatively higher individual income and a younger, better-educated population, since those areas are more likely to attract subscriptions. At the same time, socioeconomic characteristics such as income, age, and education are correlated with voting behavior, which potentially biases estimates of the effect of Internet availability on voting behavior. ${ }^{1}$ To date, research addressing these endogeneity concerns largely focuses on the introduction period of the very first ADSL technology in the 2000s, during which download speeds fell in the range of 256 or $385 \mathrm{Kbps}$. However, evidence based on the introduction of ADSL does not encompass the information and mobilization role of Web 2.0 applications such as blogs, wikis, and social network or video sharing sites, all of which have potentially played an important and expanding role in mobilizing political participation in more recent years. ${ }^{2}$

In this paper, we examine how broadband Internet affects political behavior in the Web 2.0 era. We provide quasi-experimental evidence based on a unique public broadband delivery

\footnotetext{
${ }^{1}$ Previous empirical studies address this demand-side endogeneity by exploiting preexisting voice telephony networks (Czernich, 2012; Campante, Durante, and Sobbrio, 2013; Falck, Gold, and Heblich, 2014), legal discontinuities across states (Larcinese and Miner, 2012), distance to backbone (Miner, 2015), and land topography or rainfall data (Jaber, 2013; Gavazza, Nardotto, and Valletti, 2015) to instrument for broadband Internet provision.

${ }^{2}$ For example, a meta-analysis of correlational evidence by Boulianne (2015) suggests a positive association between social media use and various forms of political engagement.
} 
program in the Province of Trento (Italy) aimed at the swift and complete coverage of previously underserved (rural, remote, and sparsely populated) areas with next-generation ADSL2+ broadband infrastructure (delivering speeds of up to $20 \mathrm{Mbps}$ ) over the period 2011-2014.

Our identification strategy relies on the exogenous (spatial and temporal) variation in ADSL2+ broadband availability generated by the public program. In particular, we take advantage of the staged installation of ADSL2+ infrastructure and employ a difference-indifferences approach controlling for year and municipality fixed effects. The latter allows differencing away preexisting location-specific conditions (such as first-generation broadband accessibility) and hence identifying the independent effect of ADSL2+ availability on changes in voting behavior.

We combine administrative data on election outcomes with information on ADSL2+ roll-out timing across the municipalities targeted by the policy and find significantly positive effects of ADSL2+ availability on electoral turnout. These positive effects increase in ADSL2+ exposure over time. Results on party vote share show significant ideological shifts, with established center-left parties and, albeit with a minor magnitude, right-fringe parties gaining from ADSL2+ diffusion mainly at expense of established center-right parties. Yet, these shifts vanish with increasing ADSL2+ exposure and hence are likely not persistent over time. Overall, placebo estimates corroborate a causal interpretation of our results.

Furthermore, we find evidence based on household survey data and ADSL subscription rates that policy-induced ADSL2+ availability significantly increased overall Internet and broadband take-up among private households. This suggests that ADSL2+ availability affects voting behavior primarily through actual adoption by private households (rather than a speed upgrade). Alternative channels for the found effects, such as positive local labor market effects or locally 
tied candidates, receive no support in our data. Assuming that adoption is the only mechanism underlying the availability effects allows for ADSL2+ availability to serve as an instrument for broadband adoption. Invoking the exclusion restriction, we provide two-sample instrumental variables estimates identifying substantial positive local average treatment effects on voter turnout among adopting households.

These findings contribute to the growing body of empirical literature on whether and, if so, how political participation is affected by mass media, such as TV (see, e.g., Gentzkow, 2006; DellaVigna and Kaplan, 2007; Enikolopov, Petrova, and Zhuravskaya, 2011; Durante and Knight, 2012; Durante, Pinotti, and Tesei, 2014; Barone, D’Acunto, and Narciso, 2015), radio (Strömberg, 2004), and newspapers (e.g. Gerber, Karlan, and Bergan, 2009; Gentzkow, Shapiro, and Sinkinson, 2011; Drago, Nannicini, and Sobbrio, 2015). Our paper is especially closely related to recent empirical literature assessing the political effects of the introduction of firstgeneration broadband infrastructures in Germany (Czernich, 2012; Falck, Gold, and Heblich, 2014), Italy (Campante, Durante, and Sobbrio, 2013), the United States (Larcinese and Miner, 2012; Jaber, 2013), Malaysia (Miner, 2015), and the United Kingdom (Gavazza, Nardotto, and Valletti, 2015). With respect to voter turnout, Czernich (2012), Larcinese and Miner (2012), and Jaber (2013) find a positive effect of broadband availability, whereas Miner (2015) finds no such effect, and Falck, Gold, and Heblich (2014), in line with Gavazza, Nardotto, and Valletti (2015), document a negative turnout effect. Campante, Durante, and Sobbrio (2013) find an initially negative effect, which, interestingly, reverses by the 2013 parliamentary elections in Italy. ${ }^{3}$

\footnotetext{
${ }^{3}$ With respect to broadband effects on changes in party votes, Falck, Gold, and Heblich (2014) find no systematic benefits for specific parties. Larcinese and Miner (2012) and Jaber (2013) find that Internet penetration is associated with a rise in the Democratic vote share in U.S. presidential elections. Campante, Durante, and Sobbrio (2013) find a reduction of vote shares for extreme parties (especially left-wing). Miner (2015) finds that in Malaysia, opposition parties took advantage of the introduction of the Internet, resulting in a shift of votes from the incumbent party in a semi-authoritarian regime.
} 
None of these studies evaluates the political effects of the ongoing update of broadband infrastructure toward advanced high-speed technologies, which is a key contribution of our paper. Moreover, the identification strategy of our analysis is based on a rare broadband delivery policy, the validity of which is confirmed by a pre-policy placebo analysis. In contrast to previous research we are able to show the causal link between broadband availability and adoption, suggesting that actual adoption by private households is likely the main channel through which advanced broadband availability affects voting behavior. In exploiting a public program targeted explicitly at rural and remote areas, we identify effects that are naturally limited in their generalizability. However, the deployment of fast and ultra-fast broadband in rural areas is an item of increasing interest on the digital agendas of OECD countries.

The paper is structured as follows: Section 2 describes the ADSL2+ policy, Section 3 introduces the data used, Section 4 describes the identification strategy, and Section 5 presents the main results as well as robustness checks and evidence on potential mechanisms. The final section concludes.

\section{The ADSL2+ Policy}

The entire territory of the Province of Trento had full coverage with first-generation broadband technology (up to $2 \mathrm{Mbps}$ ) by 2010, but there was a rural-urban digital divide with respect to next-generation ADSL2+ technology (download speeds up to $20 \mathrm{Mbps}$ ). Hence, in September 2010, the local authority decided (Reg.delib.n.2204 and n.2528) to provide a 8.3-million-euro subsidy via public tender for the equipment of access points in all (mainly rural) areas not privately supplied. 
Demand factors are unlikely to have played a role in roll-out timing across the municipalities targeted by the policy. The local government provided no guidelines as to roll-out or geographical timing of the intervention, its main concern being to ensure full coverage and to comply with the Europe 2020 objectives by end-2013. Also Telecom Italia-the telecom provider that won the public tender-was unlikely to have had any temporal or territorial roll-out preferences: the strategically most important areas were not part of the intervention and all municipalities targeted by the intervention would be covered within a relatively short time. The rollout of broadband access points started in the spring of 2011 and complete coverage was achieved by the end of January 2014.

According to Telecom Italia, the main factors determining roll-out timing were the technical features of preexisting ADSL technology in the municipalities targeted by the policy. At the time of program start, all municipalities were equipped with some sort of first-generation broadband technology, either via fixed (ADSL) or wireless infrastructure. ${ }^{4}$ Technically, it was convenient for Telecom Italia to start ADSL2+ rollout at those access points where a fixed ADSL infrastructure was already available. In fact, by the time of program start in 2011, about 85 percent of the targeted municipalities had access to a ADSL infrastructure of either up to $7 \mathrm{Mbps}$ (66.5 percent) or up to 1.2 Mbps (so-called ADSL-Lite) connectivity (18.6 percent) (see Table 1). With respect to delivered speed, both types of infrastructure are notably inferior to the ADSL2+ technology (delivering up to $20 \mathrm{Mbps}$ ) installed via the public program. In our empirical strategy, we account for the potentially endogenous presence of previous inferior ADSL infrastructure and other time-invariant differences across municipalities by employing municipality fixed effects in a difference-in-differences framework.

\footnotetext{
${ }^{4}$ Broadband cable Internet via infrastructures used for cable television was and is to date not available in the Province of Trento.
} 
[Table 1 about here]

In Table 1, we provide a comparison of demographic, economic, and geographic characteristics (measured in the pre-program period) between municipalities targeted and not targeted by the ADSL2+ policy. The former are relatively less urbanized, less economically active, and geographically more remote. In what follows, our analysis focuses exclusively on municipalities targeted by the broadband diffusion policy. We therefore exclude the more urban municipalities in the Province of Trento, which, by program start, had already been equipped with privately provided ADSL2+. Consequently, we estimate effects of broadband diffusion on election outcomes in relatively remote and rural areas.

Data on the exact timing of ADSL2+ rollout are provided by Telecom Italia. We use the day of activation of the respective access point instead of installation in order to capture the actual exposure of a household in a given municipality to the new technology. Note that in our main analysis we estimate the effects of ADSL2+ availability and not the effects of its use on voting behavior. However, we provide evidence on the adoption channel in Section 5.3 based on household survey data and ADSL subscription rates. We exclude eight municipalities that experienced territorial consolidations in $2010 .^{5}$ Our final sample consists of 159 municipalities.

[Figure 1 about here]

[Figure 2 about here]

Figure 1 displays the sample distribution of treatment intensity among municipalities targeted by the policy. We define treatment intensity as the number of days a municipality has been exposed to ADSL2+ broadband accessibility in the period between program start and February 24,2013 , the date of the 2013 national elections in Italy. The variability in treatment intensity is

\footnotetext{
${ }^{5}$ The municipalities of Pieve di Ledro, Bezzecca, Concei, Molina di Ledro, Tiarno di Sopra, and Tiarno di Sotto were merged into the new municipality of Ledro. Comano Terme was formed by merging the two municipalities of Bleggio Inferiore and Lomaso.
} 
considerable, which benefits the estimation of treatment effects across the full range of treatment intensity. Figure 2 depicts the geographical distribution of treatment intensity across municipalities. White areas indicate municipalities that were not subject to the ADSL2+ diffusion policy and dark blue areas are the municipalities that experienced territorial variations. Both are excluded from the analysis.

\section{Election Data and Institutional Background}

Based on the Italian national elections of 2008 and 2013, we examine the impact of ADSL2+ provision on voting turnout and party support. The period 2008-2013 overlaps with the policyinduced ADSL2+ rollout (2011-2014), as well as with the emergence of now widely used Web 2.0 applications such as new social media (Facebook, Twitter) and YouTube. To illustrate the approximate timing of the emergence of these technologies, Figure 3 shows a weekly popularity index ${ }^{6}$ of Google searches for the terms "Facebook," "Twitter," and "YouTube" from 2004 onward and, for comparison, the popularity of online searches for the two national newspapers having the highest circulation figures: Corriere della Sera and La Repubblica. It is obvious from Figure 3 that "Facebook" has dominated the search popularity index since its emergence around December 2008 - which was after the national elections in February 2008. By the 2013 elections, Facebook was widely known and used in Trentino/South-Tyrol and in Italy as a whole. "YouTube" was already a relatively popular search term by 2008. The online search term "Twitter," compared to "YouTube" and "Facebook," is significantly less popular throughout the analysis period. The popularity of online searches for the two main national newspapers is negligible relative to "Facebook."

\footnotetext{
${ }^{6}$ The popularity index is calculated for each week as the number of Google searches for the respective term divided by the total weekly searches in the respective geographical area (here, Italy or Trentino/South-Tyrol), scaled to a range of 0 to 100 (100 representing the highest point on the chart).
} 
[Figure 3 about here]

We use the 2006 national elections to make placebo estimations for the pre-policy period 2006-2008. Data on election outcomes at the municipality level are from the Italian Ministry of the Interior (http://elezionistorico.interno.it).

We measure effects of ADSL2+ availability on three aspects of voting behavior-voter turnout, invalid vote, and party support. Voter turnout is calculated as the total number of votes (valid or invalid) divided by the number of eligible voters. Invalid vote is the share of null or "white" votes among the total of eligible voters. While voter turnout and the incidence of invalid votes allow us to estimate the effect of advanced broadband access on political participation, party affiliation indicates whether advanced broadband availability has an impact on political preferences.

To investigate the hypothesis that broadband availability may lead to ideological polarization or self-segregation, we distinguish six distinct groups of parties according to their ideological orientation across the political spectrum on a conventional left-right axis: (1) left-fringe parties, (2) established center-left parties, (3) center and liberal parties, (4) established center-right parties, (5) right-fringe parties, and (6) others and regionalists parties. The classification of parties into these groups is described in Table A2 in Appendix and roughly follows the classification employed in Falck, Gold, and Heblich (2014) for Germany. We employ both party group vote shares relative to the total number of valid votes as well as vote shares relative to the total number of eligible voters. The latter allows controlling for the positive impact on turnout documented below. 
Italy is a parliamentary democracy based on a bicameral legislative system (Chamber of Deputies and Senate ${ }^{7}$ ). From the 1990s onward, after a judicial investigation called Mani pulite, the Italian political arena has been mainly characterized by two large coalitions: the center-right led by Silvio Berlusconi, and the center-left (social democrats) led by various political leaders. The two coalitions basically alternate in governing Italy (for a detailed discussion, see Bosco and McDonnell, 2015). Despite the two mainstream coalitions, the political situation in Italy is somewhat fragmented, with numerous left-fringe parties attracting considerable vote shares and a relatively lower number of smaller right-fringe parties.

In this study we focus on the 2006, 2008, and 2013 national parliamentary elections for the Chamber of Deputies. ${ }^{8}$ The 2006 national election took place after a five-year period of centerright government, and was won by a coalition of center-left and left-fringe parties. In 2008, political tensions within the government coalition led to new elections that were won by the center-right coalition. During the financial crisis, a "technocratic" government supported by the main political parties took power in 2011 without elections. After two years, the government lost political support and new elections were held in 2013. The new government was a grand coalition between center-left, center, and center-right parties.

[Table 2 about here]

Table 2 sets out summary statistics for the election outcomes in 2008 and 2013, as well as for 2006, which serves for placebo analysis. For our sample of 159 municipalities, voter turnout in parliamentary elections decreased by 3.4 percentage points from 2006 to 2008 , and by another

\footnotetext{
${ }^{7}$ The former is elected by the universe of eligible voters (Italian citizens aged 18 and older); only individuals aged at least 25 years are entitled to vote for the Senate.

${ }^{8}$ We focus exclusively on national parliamentary elections so as to provide results comparable to previous literature. In contrast to Campante, Durante, and Sobbrio (2013), we refrain from analyzing municipal elections since the majority of municipalities in the Province of Trento had not yet had local elections in the post-ADSL2+ policy period under investigation.
} 
5.5 percentage points from 2008 to 2013 . Voter turnout reached a level of 79 percent in 2013 . Invalid votes increased by 0.5 percentage points from 2008 to 2013 (and by 0.3 percentage points from 2006 to 2008). With respect to party vote shares, in 2013, left-fringe and established center-left parties reached 3 percent and 19.8 percent, respectively. Center and liberal parties obtained a vote share of 24.4 percent. Established center-right and right-fringe parties reached 26.1 and 0.9 percent, respectively. The vote share for other and local parties was in sum 25.9 percent. Overall, with respect to the 2006 and 2008 elections, there was a significant increase in vote shares for center and liberal parties as well as for other and local parties, whereas vote shares decrease for all other party groups.

Annual information on demographic characteristics at the municipality level was obtained from inter-censual population estimates by ISTAT (the Italian National Institute of Statistics) and information on per capita declared personal income was obtained from the Italian Ministry of Economy and Finance. Descriptive statistics for these variables are reported in Table 2; Table A3 in the Appendix provides detailed information on data sources.

\section{Empirical Strategy}

Our identification strategy relies on the staged ADSL2+ rollout of the policy intervention. Under the assumption of exogenous variation in roll-out timing with respect to trends in local municipality characteristics, we use a difference-in-differences specification controlling for timeinvariant location-specific factors. We run regressions of the following type:

$$
Y_{m t}=\alpha+\beta \text { Treat }_{m t}+\boldsymbol{\omega}_{m t}^{\prime} \delta+\gamma_{m}+\vartheta_{t}+\varepsilon_{m t}(1)
$$


where $\mathrm{Y}$ represents the respective election outcome in municipality $m$ in election year $t$ (with $t=[2008 ; 2013])$. Treat $_{m t}$ indicates the treatment status of voters in municipality $m$ in election year $t$. Depending on the specification, we define the treatment status either in a binary way, indicating whether or not residents in municipality $m$ in election year $t$ had access to ADSL2+ broadband, or as a continuous measure of treatment intensity, that is, the number of days of exposure to broadband accessibility as of the day of the respective election. We also add a specification employing treatment intensity categories in order to investigate potential nonlinearities in the impact of treatment intensity.

Unobservable factors that are time invariant and fixed at the municipality level are controlled for by municipality fixed effects $\left(\gamma_{m}\right) ;{ }^{9}$ time shocks common to all municipalities are absorbed by the year indicator $\vartheta_{t}$. $\boldsymbol{\omega}_{m t}$ is a vector that captures observable time-varying socioeconomic characteristics of the municipalities. $\varepsilon_{m t}$ is an error term.

The parameter $\beta$ estimates the causal effect of interest under the common trend assumption. This parameter is identified through variation in voter's election decisions between national elections in 2008 (pre-ADSL2+) and 2013, and the comparison of this difference either between the group of voters in municipalities with and without broadband access by February 2013 (in case of binary treatment) or voters residing in municipalities with different treatment intensity (in case of the continuous or "category" specification). The key identifying assumption is that the trend in election outcomes would have been the same for voters residing in relatively earlier and later treated municipalities in the absence of treatment (conditional on $\boldsymbol{\omega}_{m t}$ ). We provide a

\footnotetext{
${ }^{9}$ Note that controlling for municipality fixed effects is of central importance for a causal interpretation of our estimates. It accounts for the fact that the installation of pre-policy ADSL infrastructure of inferior speed was market-led and hence potentially nonrandom and we cannot exclude that roll-out timing was systematically associated with observed or unobserved local productive characteristics in ways that potentially confound a causal interpretation. See also discussion in Section 2.
} 
placebo analysis for the pre-policy election years 2006 and 2008 to test whether the common trend assumption is plausible.

\section{Results and Discussion}

Table 3 presents the main results and placebo estimates with respect to voter turnout and invalid votes. Table 4 presents results with respect to party vote shares, and Table 5 reports the respective placebo estimates. Throughout, we employ the various specifications of the treatment variable of voters' exposure to the ADSL2+ technology as binary (Panels A1 and B1), linear (Panels A2 and B2), and treatment intensity categories (Panels A3 and B3). All models include municipality fixed effects and a year indicator. Throughout the specifications, estimation results are reported both with and without control variables.

\subsection{Voting Turnout and Invalid Votes}

Columns 1 and 2 of Table 3 show a positive effect of ADSL2+ broadband availability on voter turnout. The positive effect is not significant in the binary specification of the treatment variable. However, it is statistically significant at the 10 percent level in the linear specification without controls and significant at the 5 percent level when controlling for socioeconomic characteristics of the municipalities. These estimates suggest that ADSL2+ exposure of roughly three months increases voter turnout by about 0.2 percentage points. ${ }^{10}$ The categorical specification of the exposure variable reveals that the positive effect of advanced broadband availability on voter turnout mainly stems from municipalities that experienced a relatively long exposure of 18 months or more. These results indicate that, with respect to municipalities with zero ADSL2+

\footnotetext{
10 The estimates resulting from weighted regressions (by the number of eligible voters) are virtually identical. Results are available from the authors upon request.
} 
exposure as of February 2013, municipalities with 18 months or more exposure exert an almost 3.3 percentage point higher increase in voting turnout from the 2008 to the 2013 national election. The fact that the increase in voter turnout appears to be significant only for those municipalities with relatively longer exposure suggests that advanced broadband effects might need some time to mature and hence are found to be stronger in the medium to long run than in the short term.

[Table 3 about here]

Overall, this finding is somewhat at odds with Falck, Gold, and Heblich's (2014) estimate of a 3.4-3.6 percentage point decrease in voting turnout with the introduction of DSL technology in West Germany during the early 2000s. These different findings might be explained by the fact that Internet usage and the "Internet" itself were comparatively basic in the early days of broadband technology (with a minimum speed of 256 or $385 \mathrm{Kbps}$ ) relative to high-speed Internet usage in 2013 when more elevated download speeds were becoming standard and use of new social media and advanced Web 2.0 applications intensifying. In fact, Web 2.0 applications (such as Facebook, Twitter, YouTube, and blogs) may have become effective ways of expressing and diffusing political opinions and hence advanced broadband may play a different role in political mobilization in the social media era than was the case during the introduction of DSL technology. Our results are somewhat in line with Campante, Durante, and Sobbrio (2013), who find for Italy as a whole a positive (albeit not statistically significant) broadband effect of about 1.9 percentage points on voter turnout for the 2013 parliamentary elections. It may well be that we find a stronger broadband effect in comparison with Campante, Durante, and Sobbrio (2013) because we focus our analysis on rural and relatively sparsely populated areas. These areas may 
simply profit more strongly from a marginal increase in information availability than do urban areas where there is already a high level of availability.

Note that controlling for municipalities' socioeconomic characteristics only slightly affects the treatment coefficient in the various specifications. This makes us confident that - conditional on controlling for time-invariant municipality characteristics via municipality fixed effectstime-varying socioeconomic characteristics do not systematically bias our parameter estimate of interest.

To more explicitly test the common trend assumption underlying our identification approach, we provide placebo estimates in Panels B1-B3 of Table 3. That is, we run regressions on voting turnout for the pre-policy period national parliamentary elections of 2006 and 2008, assigning treatment measures as if the policy took place between 2006 and 2008 (as opposed to 2011 and 2013). This being a placebo treatment, there should be no significant correlation between fake treatment and voting outcomes in the absence of underlying differential trends between municipalities of different treatment status or intensity for reasons other than the actual ADSL2+ treatment. This placebo analysis hence provides a powerful test of the common trend assumption. In fact, throughout the various specifications, Panels B1-B3 show no significant association between placebo treatment and election turnout in the pre-policy election years of 2006 and 2008. This confirms the assumption that the positive turnout effect found is not driven by underlying non-policy-related trends in voting turnout.

\section{[Figure 4 about here]}

Figure 4 illustrates the positive turnout effect and the placebo test. First, we plot for each municipality the percentage point change in voter turnout between the elections of 2008 and 2013 against the days of exposure to ADSL2+ technology experienced as of the 2013 election 
date. The fitted line clearly indicates a positive slope. Second, we display the placebo check by plotting the change in turnout between the elections of 2006 and 2008 against the days of ADSL2+ exposure as of the 2013 election date. Confirming the regression results presented in Table 3, the fitted line suggests no systematic relationship between changes in voter turnout and ADSL2+ exposure previous to the actual installation of the ADSL2+ infrastructure.

Columns 3 and 4 of Table 3 are concerned with invalid votes. Using invalid vote share as an outcome allows testing whether our finding of increased electoral turnout is driven by an increase in invalid votes. If such is the case, we should find a negative broadband effect on the incidence of invalid votes. The results in Columns 3 and 4 of Table 3 suggest that this has not been the case. No statistically significant effects emerge with respect to any of the various ADSL2+ exposure measures and the point estimates are close to zero in the baseline specifications (Panels A1-A3) as well as in the placebo analysis (Panels B1-B3). Overall, there is no evidence that the increase in voter turnout is driven by an increase in invalid votes.

\subsection{Party Vote Shares}

Table 4 presents the estimated coefficients for the impact of broadband Internet on party vote shares. Overall, the results indicate that established center-left parties benefited significantly from ADSL2+ broadband availability, whereas the established center-right parties lost vote shares; right-wing fringe parties appear to have benefited moderately. In our binary specification, ADSL2+ accessibility is associated with an increase in vote share of about 3.7 percentage points for established center-left parties and a reduction in the vote share of established center-right parties of about 2.4 percentage points; right-wing fringe parties gain about 0.5 percentage points.

[Table 4 about here] 
These results are not reflected in the linear specification, which indicates that advanced broadband effects on party votes are not linearly increasing with treatment intensity. Indeed, this is confirmed by estimates based on the "category" specification. We find that the effects on vote share for established center-left, established center-right, and right-wing fringe parties are relatively stable for up to 18 months of ADSL2+ exposure but smaller and not statistically significant for treatment intensity beyond 18 months. The latter finding suggests, first, that changes in vote shares induced by ADSL2+ availability cannot be attributed to the increase in voting turnout, which was mainly found for treatment intensities beyond 18 months. Second, this finding might indicate that, in contrast to effects on turnout, advanced broadband availability effects on vote share are rather short-lived and might not have much influence on political preferences in the long run. Hence, our results neither clearly confirm nor reject the hypothesis of self-segregation in online information consumption. While we find some evidence of significant vote shifts across the ideological spectrum, these might not persist in the medium to long run.

[Table 5 about here]

Placebo tests presented in Table 5 support the validity of our main results. Neither estimates in the binary nor in the linear specification are significantly different from zero. With respect to the "category" specification, estimates for single categories are weakly statistically significant at the 10 percent level; however, no systematic pattern is evident. Additionally, either the already weak statistical significance vanishes when adding control variables or the estimates are of opposite sign as the baseline results. We thus conclude that, overall, the placebo analysis corroborates our main findings. 
One might wonder to what extent the shifts in party votes are due to the increase in voter turnout documented in Section 5.1. As discussed above, there might not be any relationship between the two phenomena given the finding that turnover effects and party vote effects have very different timing: only a relatively long ADSL2+ exposure appears to have a significant effect on voter turnout, whereas effects on party votes are more immediate. We provide additional results to further investigate this issue.

[Table 6 about here]

Table 6 reports results analogous to estimations presented in Table 4, where the dependent variable is vote shares relative to the total number of eligible voters (instead of number of valid voters), thus allowing us to control for the positive ADSL2+ impact on voter turnout. Qualitatively, the results are very much in line with those set out in Table 4: a significant increase in vote share for established center-left parties, a moderate but significant increase for right-wing fringe parties, and a decrease for the established center-right. Point estimates are slightly smaller than those set out in Table 4, and we observe a slight increase in precision. In the binary specification of ADSL2+ exposure, we now find a 2.9 (instead of a 3.7) percentage-point increase for established center-left parties (see Column 4 of Table 6), a reduction in vote share of 2.2 (instead of 2.4) percentage points for the established center-right, and an increase of 0.3 (instead of 0.5 ) percentage points with respect to right-fringe parties. Overall, this suggests that the increase in party vote shares for center-left and right-fringe parties documented in Table 4 cannot be fully attributed to the increase in voter turnout.

\section{[Table 7 about here]}

Table 7 presents estimation results with respect to two specific parties, Movimento 5 Stelle (M5S) and Fare per Fermare il Declino, both of which emerged in the national elections of 2013 
and are said to represent the most web-friendly political movements in Italy (see, e.g., Campante, Durante, and Sobbrio, 2013). In fact, Campante, Durante, and Sobbrio (2013) find these two parties to benefit significantly from broadband exposure in the 2013 elections in Italy. Our main results, presented in Table 4, do not suggest a significant broadband effect for the party grouping of "others and local parties" (in which we classify the M5S movement) or center and liberal parties (the party group to which Fare per Fermare il Declino is allocated). However, we investigate this issue further by providing results separately for these two movements. Note that neither M5S nor Fare per Fermare il Declino took part in the parliamentary elections of 2008. Hence, both parties' vote share in 2008 is set to zero.

The findings presented in Table 7 indicate no systematic effect of ADSL2+ availability on the respective vote shares. Most estimates are not significantly different from zero. One exception is ADSL2+ exposure in the linear specification with respect to vote shares for Fare per Fermare il Declino, but the estimate - 0.04 percentage points - is hardly distinguishable from zero (see Column 4, Panel A2, Table 7) and is not reflected in either the binary or the category specification. Another exception is a significantly negative effect of up to six months of ADSL2+ exposure, amounting to about 3.5 percentage points (see Column 2, Panel A3). Yet, no significant effects are found for longer exposure times in either the linear or binary specification. Thus, these results do not show positive broadband exposure effects on political support for M5S and Fare per Fermare il Declino with respect to our quasi-experimental setting in the Province of Trento.

Overall, our results concerning party vote shares indicate that the availability of advanced broadband technology may not only affect overall political participation, but also political preferences, that is, who people vote for-at least in the relatively short run. In the medium to 
long run, however, we find that individuals do not necessarily change their political views after being exposed to more and less costly information from high-speed Internet. That is, our evidence cannot clearly support nor unambiguously reject the notion that advanced Internet exposure cements political positions via ideological self-segregation (see, e.g., Sunstein, 2007; Sood, Lelkes, and Iyengar, 2015).

\subsection{Additional Evidence on Exogeneity of the ADSL2+ Policy}

The placebo results presented in Panels B1-B3 of Table 3 with respect to voter turnout, and in Table 5 with respect to party vote shares, are informative about and support the plausibility of the common trend assumption underlying our identification approach. In this section, we provide further placebo analysis testing whether ADSL2+ availability is systematically correlated with changes in socioeconomic characteristics of the municipalities in the pre-policy period. If we find the ADSL2+ policy to be exogenous to pre-policy trends in observed municipality characteristics, we will be more confident in the causal interpretation of the results in the previous section.

[Table 8 about here]

The results set out in Table 8 replicate the placebo specification in Panels B1-B3 of Tables 3 and 5 using as the dependent variable observable time-varying socioeconomic characteristics of the municipalities. Specifically, we use the female population share, the share of population aged $18-65$, the population share aged more than 65 years, the share of net migration, and the share of foreigners. The results in Table 8 illustrate that, overall, the observed municipality characteristics are not systematically correlated with the timing of the ADSL2+ broadband expansion. Most 
estimates are not statistically different from zero. Two single coefficients are significant, but only weakly so (at the 10 percent level).

[Table 9 about here]

Unfortunately, information on the control variable of declared personal income is not available for the year 2006. In addition, there are no inter-censal estimates for population counts by education level available from the Italian National Institute of Statistics (ISTAT). To investigate exogeneity of the ADSL2+ diffusion policy with respect to the educational characteristics of the municipalities, we hence provide estimates based on information from the decennial population censuses of 2001 and 2011. Note, however, that 2011 is not strictly prepolicy since the ADSL2+ diffusion started in the spring of that year. Table 9 reports the results of this exercise and they roughly confirm that the timing of ADSL2+ diffusion across municipalities is not related to pre-policy trends in educational attainment of the resident population.

\subsection{Potential Mechanisms}

To shed light on the mechanisms through which ADSL2+ broadband availability might affect political participation, we first investigate whether broadband availability is systematically correlated with changes in the municipalities' socioeconomic characteristics. We are particularly interested in exploring whether the effects are driven by a positive effect of labor market activity, that is, an increase in residents' income. It is commonly held that the propensity to vote increases with economic resources (Brady, Verba, and Schlozman, 1995). Table 10 reports the results of this exercise. ADSL2+ exposure is not systematically related to changes in municipalities' socioeconomic characteristics. Out of 36 coefficients, only two are statistically significant (one at 
the 10 percent level and one at the 5 percent level $^{11}$ ). Moreover, ADSL2+ exposure does not appear to have significantly increased per capita income. Therefore, the regressions in Table 10 support the notion that ADSL2+ availability does not affect political participation via a positive income effect or through other policy-induced changes in socioeconomic characteristics.

[Table 10 about here]

Second, we examine whether local ties of candidates in the 2013 election could have driven the effects on political participation. We collected information on whether any of the candidates had their place of residence, place of birth, place of work, or place of public office in one of the municipalities targeted by the ADSL2+ policy $^{12}$ and investigated whether having a locally tied candidate is systematically correlated with both ADSL2+ exposure and changes in voter turnout. This ad-hoc evidence is displayed in Figure 5, which reproduces Figure 4-that is, we plot for each municipality the percentage-point change in voter turnout between the elections of 2008 and 2013 against the days of exposure to ADSL2+ technology experienced as of February 24, 2013 - and additionally flags those municipalities with a locally tied candidate. The figure reveals that our main results are unlikely being driven by the presence of local candidates. The municipalities with locally tied candidates do not systematically experience higher ADSL2+ exposure and at the same time stronger changes in voter turnout. For municipalities with tied candidates to drive results, one would expect those municipalities to systematically cluster in the upper-right part of the figure.

[Figure 5 about here]

\footnotetext{
${ }^{11}$ Specifically, we find that very strong exposure intensity is associated with a relatively lower increase in the local share of foreigners over time. While results presented in Column 2 of Table 3 already indicate that our main results are robust to the inclusion of the share of foreigners as one control among others, we also test robustness to the inclusion of the share of foreigners as the only control. We find that the estimated coefficients of interest change only marginally and retain statistical significance. These additional results are available from the authors upon request.

${ }^{12}$ More detailed information on the $a d-h o c$ data collection available from the authors upon request.
} 
Third, we look at the relationship between ADSL2+ exposure and actual adoption behavior. More precisely, we examine private household ADSL subscription rates with Telecom Italia, the main telecommunications provider in the municipalities targeted by the ADSL2+ policy. Unfortunately, subscription rate information is not available before March 1, 2014 and so we have no information on subscription rates around the time of the 2008 or 2013 elections. However, we can exploit the available 2014 data to explore whether it is plausible to assume that the effects we find for ADSL2+ availability stem from actual broadband adoption by private households. It is apparent from the subscription rates measured roughly one year after the 2013 elections and shortly after the completion of full ADSL2+ coverage that subscriptions at 20Mbps were infinitesimal: there are only a total of nine subscriptions in the municipalities targeted by the ADSL2+ policy. It is highly unlikely that the effects shown above for voter turnout and party vote shares stem from this very low take-up of $20 \mathrm{Mbps}$ connections. Rather, it is possible that the ADSL2+ policy incentivized overall ADSL subscriptions (including those for a relatively lower speed). One can think of the ADSL2+ infrastructure installation as a de-facto information treatment that informed residents about the overall local availability of ADSL.

And, indeed, Figure 6 shows a clear positive relationship between overall local ADSL subscription rates ${ }^{13}$ at 7 Mbps or higher and ADSL2+ exposure, ${ }^{14}$ which supports the conclusion that broadband Internet availability affects voter turnout through actual take-up and use of the broadband technology.

[Figure 6 about here]

\footnotetext{
${ }^{13}$ We calculate local subscription rates as the sum of ADSL subscriptions by private households with Telecom Italia (as of March 1, 2014) multiplied by the average number of adults in households in municipalities targeted by the policy (2.2 in 2013 - data from the Longitudinal Household Survey on Living Conditions in the Province of Trento), and divided by the number of local eligible voters (as of February 24, 2013).

${ }^{14}$ ADSL2+ exposure is defined as of the 2013 election date $(24 / 02 / 2013)$ to make results comparable to our main results.
} 
[Table 11 about here]

Table 11 reports the respective regression results in Column 1 based on the binary (Panel A1), linear (Panel A2), and categorical (Panel A3) specification of ADSL2+ exposure. Note that we define ADSL2+ exposure as of the 2013 election date (February 24, 2013) for comparability with our main results. All specifications indicate a positive and strongly significant relationship between ADSL2+ exposure and local ADSL subscription rates. Results employing the categorical specification of ADSL2+ exposure clearly suggest that ADSL take-up increases with length of exposure. Compared to the least exposed municipalities, municipalities with the longest exposure exhibit an almost 21 percentage point higher subscription rate by March 2014 .

In Table 11 (Column 2) we provide results from additional analysis based on panel data from the Longitudinal Household Survey on Living Conditions in the Province of Trento (Schizzerotto and Fambri, 2008). We use a survey question that asks whether the "family possesses one of the following goods ... internet access." The main advantage of this information over the 2014 subscription data is that we can use data from the years 2008 and 2013, which exactly correspond to the election years. Furthermore, we can use the longitudinal data to run differences-in-differences regressions.

Results from panel models with household fixed effects are presented in Column 2 of Table 11 and confirm a positive effect of ADSL2+ exposure on households' Internet access. With respect to the binary measure of ADSL2+ exposure (Panel A1), the estimated coefficient is statistically significant at the 10 percent level and indicates that ADSL2+ availability increased households' Internet access on average by about 13 percentage points in the period from 2008 to 2013. The estimate with respect to the linear specification of ADSL2+ exposure (Panel A2) is also of positive sign, but not statistically significant at conventional levels. When employing the 
categorical specification (Panel A3), it is again evident that ADSL2+ effects on Internet access increase with length of exposure. Households in municipalities that have been exposed for more than 12 or more than 18 months as of the 2013 election date show a statistically significant (at the 5 percent level) increase in Internet access by about 15 to 16 percentage points, whereas effects for lower levels of exposure are smaller in size and not statistically significant.

Overall, evidence based on ADSL subscription rates as well as evidence based on the household survey strongly indicate that the diffusion of ADSL2+ infrastructure successfully incentivized broadband adoption by private households. Moreover, the estimated effect magnitudes are strikingly similar and both increase with ADSL2+ exposure. It is thus plausible to assume that the effects of ADSL2+ availability on voting behavior shown in Sections 5.1 and 5.2 stem from actual broadband adoption.

We go one step farther and provide calculations to establish the magnitude of the ADSL2+ effect among broadband-adopting households. We derive two-sample instrumental variables (TSIV) estimates (see Angrist and Krueger, 1992; Inoue and Solon, 2010) by dividing the "reduced-form" estimate of ADSL2+ availability on turnout in Table 3 by the "first-stage" estimates of ADSL2+ availability on adoption in Table 11.

[Table 12 about here]

Table 12 presents the resulting TSIV estimates with respect to the linear as well as the categorical specification of ADSL2+ exposure (employing both first-stage estimates based on ADSL subscription rates and first-stage estimates based on survey data). We look at the linear specification as well as the effect for the highest exposure category (more than 18 months) since this is where we find significant effects on electoral turnout in the main (reduced-form) analysis. 
Employing the first-stage estimate based on ADSL subscription rates (Column 2 of Table 12) we obtain a TSIV estimate of about 9 percentage points (significant at the 10 percent level) for the linear exposure measure and an estimate of about 15.4 percentage points for the highest exposure category (significant at the 5 percent level). TSIV estimates based on household survey data (Column 3 of Table 12) are relatively more imprecisely estimated and not statistically significant at conventional levels, but roughly of similar magnitude in comparison with estimates based on ADSL subscription data. Now, with a focus on adoption, these TSIV estimates represent local average treatment effects (LATE), whereas in the main (reduced-form) analysis we provide intend-to-treat (ITT) effects. Hence, for example, the ITT effect of a 3.3 percentage point increase in election turnout for 18 months of ADSL2+ exposure rises to a LATE effect of 15.4 percentage points among the actual adopters of ADSL broadband.

\section{Concluding Remarks}

The results of this study reveal that broadband availability in the era of Web 2.0 can influence political behavior, especially voter turnout. Our findings contribute to the empirical literature that has to date mainly focused on the introduction phase of the Internet. However, effects on political information and mobilization might be different in subsequent phases of diffusion of much faster broadband technology and in light of the emergence of Web 2.0 applications such as Facebook, YouTube, and Twitter.

We provide quasi-experimental evidence based on an ADSL2+ broadband provision policy in the Province of Trento (Italy). We find significant and positive effects on voter turnout as well as significant shifts in party votes. The positive effects on voter turnout increase in ADSL2+ exposure over time. Three additional months of ADSL2+ exposure are associated with an 
increase in electoral turnout of about 0.2 percentage points and 18 months or more of ADSL2+ availability increase turnout by about 3.3 percentage points. We find ADSL2+ availability to increase vote shares for established center-left and right-wing fringe parties, whereas it decreased vote shares for established center-right parties. The effects on party votes, however, vanish with increasing ADSL2+ exposure and might not represent permanent shifts.

We provide additional evidence that the effects of ADSL2+ availability are likely linked to actual broadband take-up by private households in that the ADSL2+ policy considerably increased private Internet and broadband adoption.

Although this is the first paper to provide quasi-experimental evidence, based on a public diffusion program, in the context of voting behavior and our results represent novel evidence on advanced broadband effects on political outcomes in rural areas, generalizability of our results may appear limited due to the policy's explicit targeting of rural and sparsely populated areas. However, the recent national digital strategies in OECD countries are especially concerned with broadband deployment in rural and remote areas so as to lessen the digital divide with respect to next-generation technologies (OECD 2015). With respect to such areas, we show that newgeneration broadband diffusion can boost local electoral turnout and political participation by mobilizing (former) nonvoters. Further research is needed to assess to what extent the effect documented here is specific to rural and underserved regions and whether a marginal increase of broadband availability in urban areas would yield similar results. 


\section{References}

Alterman, J. B. (1998). New Media, New Politics? From Satellite Television to the Internet in the Arab World. Washington Institute for Near East Policy, Policy Paper No. 48.

Angrist, J. D., and Krueger, A. B. (1992). The Effect of Age at School Entry on Educational Attainment: An Application of Instrumental Variables with Moments from Two Samples. Journal of the American Statistical Association, 87(481), 328-336.

Axford, B., and Huggins, R. (eds.) (2001). New Media and Politics. London: Sage.

Barone, G., D'Acunto, F., and Narciso, G. (2015). Telecracy: Testing for Channels of Persuasion. American Economic Journal: Economic Policy, 7(2), 30-60.

Bentivegna, S. (2006). Rethinking Politics in the World of ICTs. European Journal of Communication, 21(3), 331-343.

Bosco, A., and McDonnell, D. (2015). Italian Politics 2011: From Berlusconi to Monti. Berghahn Books.

Boulianne, S. (2015). Social Media Use and Participation: A Meta-Analysis of Current Research. Information, Communication \& Society, 18(5), 524-538.

Brady, H. E., Verba, S., and Schlozman, K. L. (1995). Beyond SES: A Resource Model of Political Participation. American Political Science Review, 89(2), 271-294.

Campante, F. R., Durante, R., and Sobbrio, F. (2013). Politics 2.0: The Multifaceted Effect of Broadband Internet on Political Participation. National Bureau of Economic Research, Working Paper No. 19029.

Czernich, N. (2012). Broadband Internet and Political Participation: Evidence for Germany. Kyklos, 65(1), 31-52.

DellaVigna, S., and Kaplan, E. (2007). The Fox News Effect: Media Bias and Voting. Quarterly Journal of Economics, 122(3), 1187-1234.

Drago, F., Nannicini, T., and Sobbrio, F. (2015). Meet the Press: How Voters and Politicians Respond to Newspaper Entry and Exit. American Economic Journal: Applied Economics, 6(3), 159-188.

Durante, R., and Knight. B. (2012). Partisan Control, Media Bias, and Viewer Responses: Evidence from Berlusconi's Italy. Journal of the European Economic Association, 10(3), $451-481$.

Durante, R., Pinotti, P., and Tesei, A. (2014). No News, Big News. The Political Consequences of Entertainment TV. "Carlo F. Dondena," Centre for Research on Social Dynamics, Università Commerciale Luigi Bocconi, Working Paper No. 63.

Dutton, W. H. (ed.) (2013). The Oxford Handbook of Internet Studies. Oxford University Press. 
Enikolopov, R., Petrova, M., and Zhuravskaya, E. (2011). Media and Political Persuasion: Evidence from Russia. American Economic Review, 101(7), 3253-3285.

Falck, O., Gold, R., and Heblich, S. (2014). E-lections: Voting Behavior and the Internet. American Economic Review, 104(7), 2238-2265.

Feddersen, T. J., and Pesendorfer, W. (1996). The Swing Voter's Curse. American Economic Review, 86(3), 408-424.

Gavazza, A., Nardotto, M., and Valletti, T. (2015). Internet and Politics: Evidence from UK Local Elections and Local Government Policies. CEPR Discussion Paper No. 10991.

Gentzkow, M. (2006). Television and Voter Turnout. Quarterly Journal of Economics, 121(3), 931-972.

Gentzkow, M., Shapiro, J. M., and Sinkinson, M. (2011). The Effect of Newspaper Entry and Exit on Electoral Politics. American Economic Review, 101(7), 2980-3018.

Gerber, A. S., Karlan, D., and Bergan, D. (2009). Does the Media Matter? A Field Experiment Measuring the Effect of Newspapers on Voting Behavior and Political Opinion. American Economic Journal: Applied Economics, 1(2), 35-52.

Gibson, R. K. (2009). New Media and the Revitalisation of Politics. Representation, 45(3), 289 299.

Inoue, A., and G. Solon. (2010). Two-Sample Instrumental Variables Estimators. Review of Economics and Statistics, 92(3), 557-561.

Kindra, G., Stapenhurst, F., and Pellizo, R. (2013). ICT and the Transformation of Political Communication. International Journal of Advances in Management Science, 2(1), 32-42.

Jaber, A. (2013). Broadband Internet and Political Behavior: Evidence from the United States. Mimeo. Available at: http://dx.doi.org/10.2139/ssrn.2353549.

Larcinese, V. (2007). Does Political Knowledge Increase Turnout? Evidence from the 1997 British General Election. Public Choice, 131(3-4), 387-411.

Larcinese, V., and Miner, L. (2012). The Political Impact of the Internet on US Presidential Elections. Mimeo. Available at: http://core.ac.uk/download/files/170/9994855.pdf.

Lassen, D. D. (2005). The Effect of Information on Voter Turnout: Evidence from a Natural Experiment. American Journal of Political Science, 49(1), 103-118.

Lievrouw, L. A., and Livingstone, S. (eds.) (2002). Handbook of New Media: Social Shaping and Consequences of ICTs. London: Sage.

Lilleker, D., and Jackson, N. (2013). Political Campaigning, Elections and the Internet: Comparing the US, UK, France and Germany, Vol. 4. Routledge. 
Miner, L. (2015). The Unintended Consequences of Internet Diffusion: Evidence from Malaysia. Journal of Public Economics, 132, 66-78.

Morgan, M., and Shanahan, J. (1992). Television Viewing and Voting 1972-1989. Electoral Studies, 11(1), 3-20.

OECD (2015). OECD Digital Economy Outlook 2015. Paris: OECD Publishing.

Pratt, A. C. (2000). New Media, the New Economy and New Spaces. Geoforum, 31(4), 425-436.

Prior, M. (2005). News vs. Entertainment: How Increasing Media Choice Widens Gaps in Political Knowledge and Turnout. American Journal of Political Science, 49(3), 577-592.

Putnam, R. (1995). Bowling Alone. Journal of Democracy, 6(1), 65-78.

Schizzerotto, A., and G. Fambri (eds.) (2008). Le Condizioni di Vita delle Famiglie Trentine. Secondo Rapporto. Trento: Edizioni 31.

Stanyer, J. (2005). Political Parties, the Internet and the 2005 General Election: From Web Presence to E-Campaigning? Journal of Marketing Management, 21(9-10), 1049-1065.

Sood, G., Lelkes, Y., and Iyengar, S. (2015). The Hostile Audience: The Effect of Access to Broadband Internet on Partisan Affect. American Journal of Political Science, forthcoming.

Strömberg, D. (2004). Radio's Impact on Public Spending. Quarterly Journal of Economics 119(1), 189-221.

Sunstein, C. R. (2007). Republic.com 2.0. Princeton, NJ: Princeton University Press. 
Figure 1. Histogram-Distribution of Municipalities by the Number of Days of ADSL2+ Broadband Exposure as of 24/02/2013

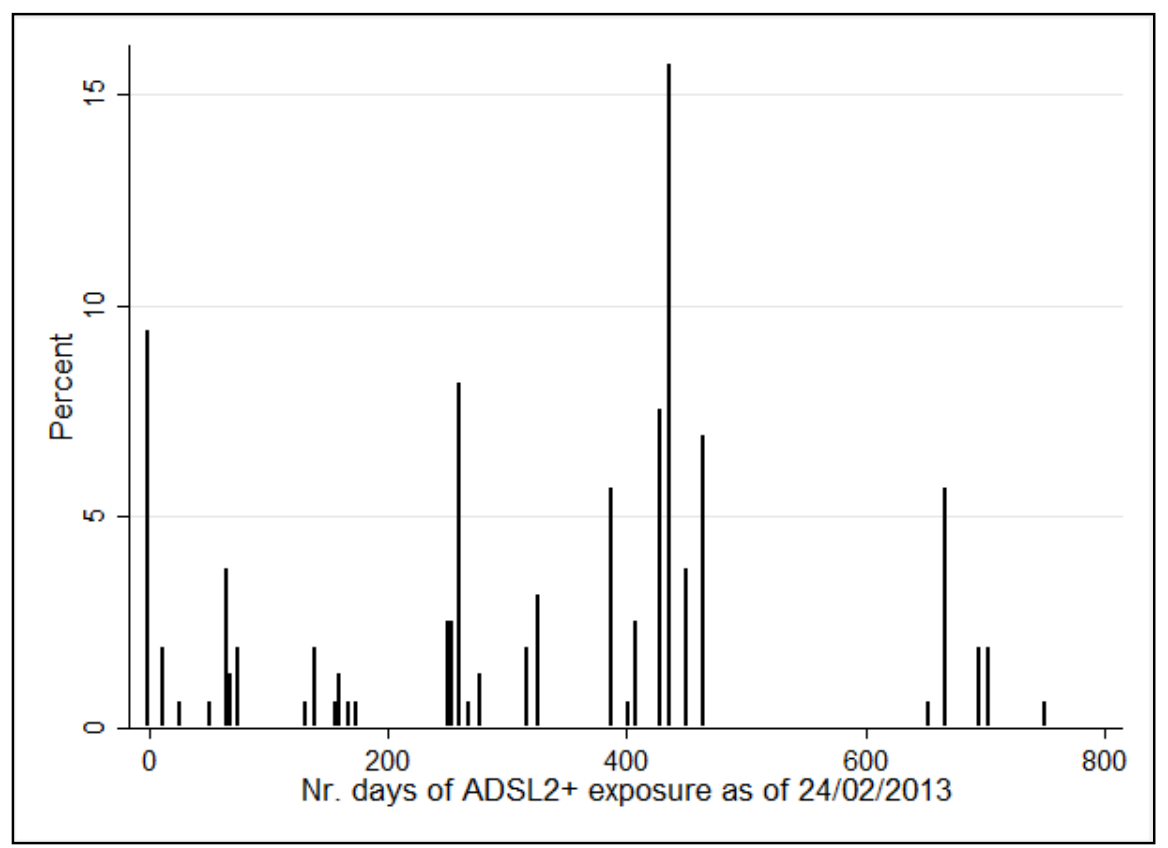

Source: Telecom Italia; own calculations.

Note: $N=159$ municipalities. 
Figure 2. Number of Months of ADSL2+ Exposure as of 24/02/2013 Across Municipalities in the Province of Trento

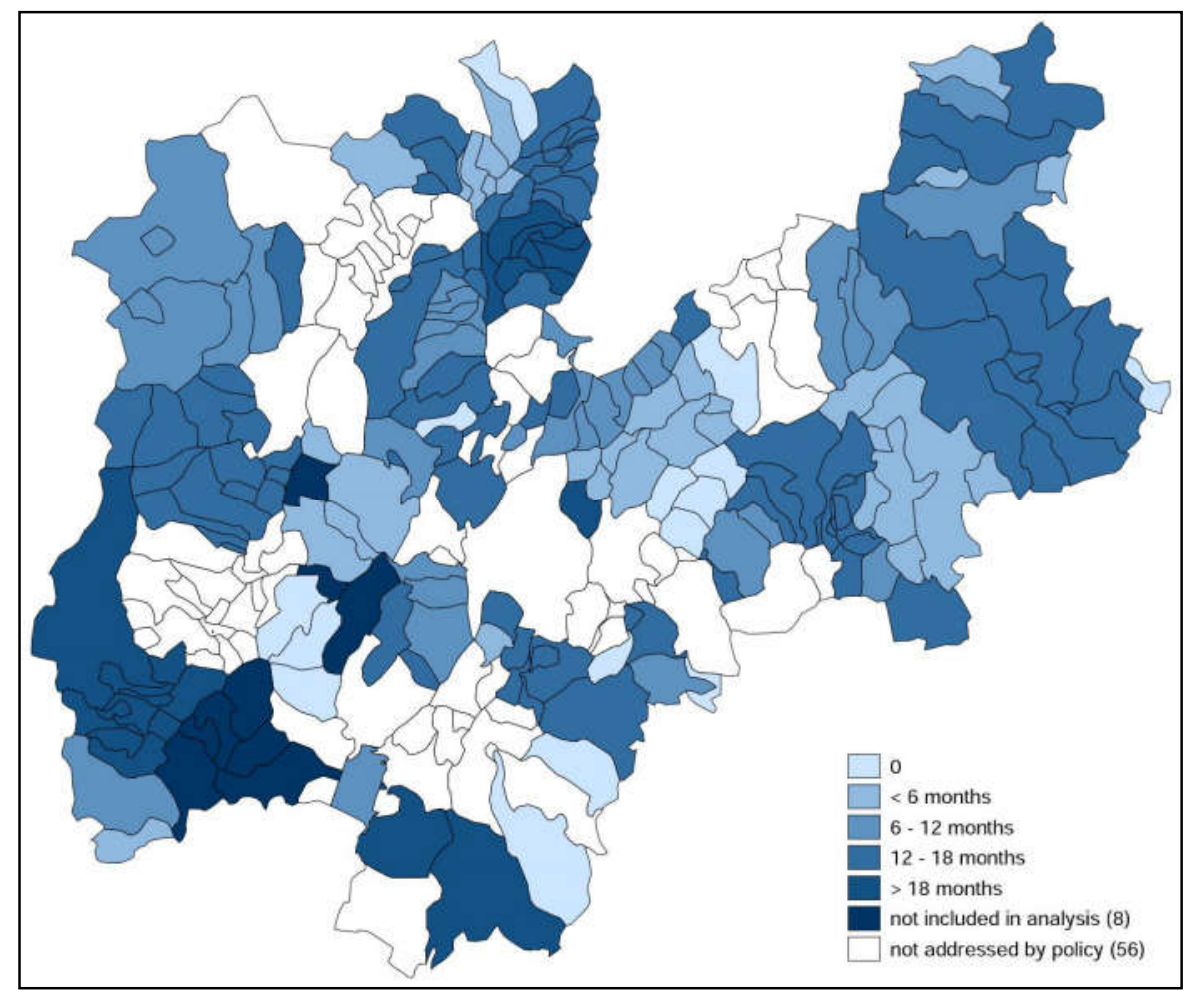

Source: Telecom Italia; own calculations. 
Figure 3. Emergence of "Facebook," "Twitter," and "YouTube" in Trentino/South-Tyrol (and Italy)
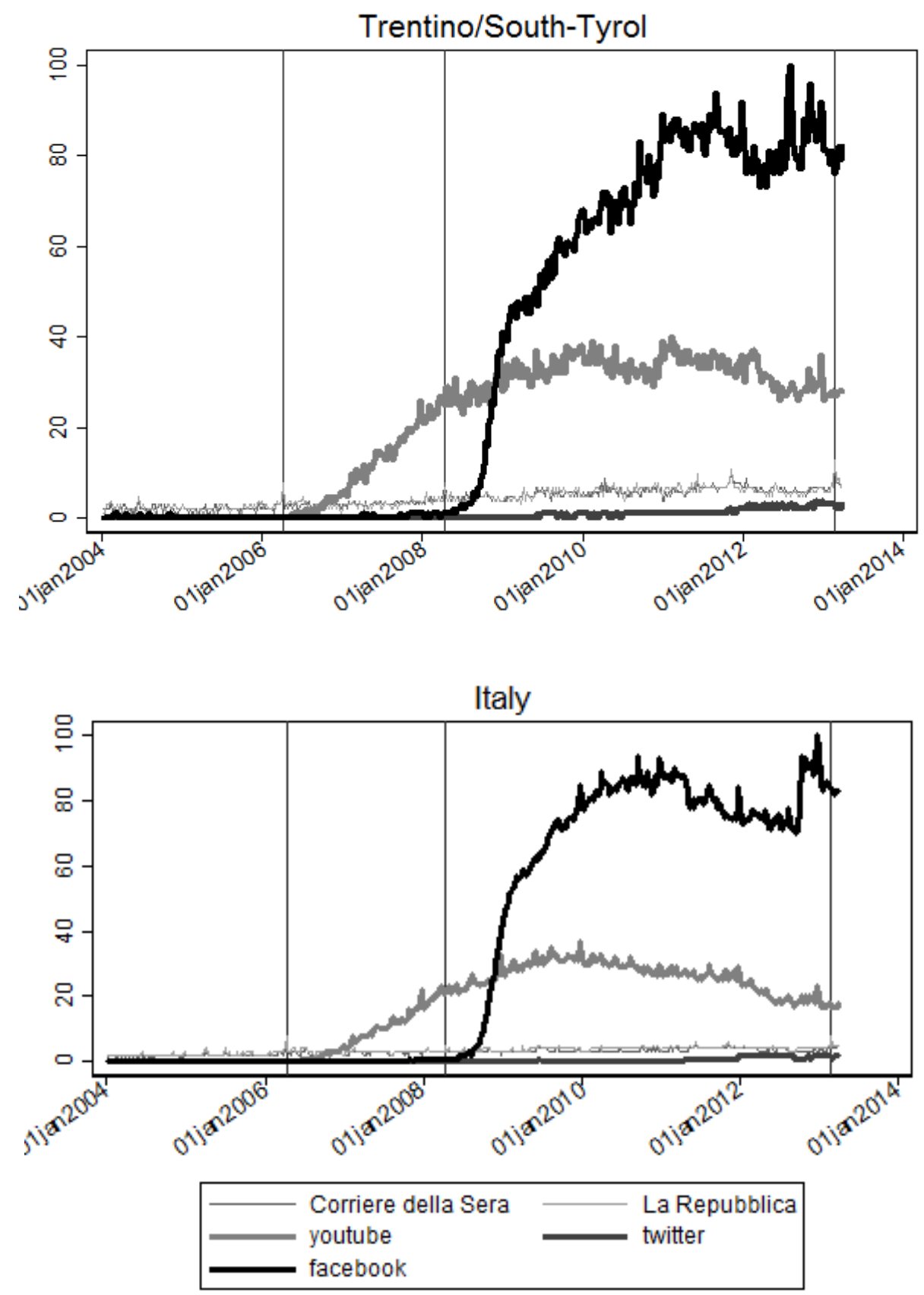

Source: Google Trends (www.google.com/trends).

Notes: Weekly data. Each data point represents the number of searches for the terms "Facebook," "Twitter," "YouTube," and online searches for the main national newspapers Corriere della Sera and La Repubblica divided by the total weekly searches in Italy, or Trentino/South-Tyrol, respectively, scaled to a range of 0 to 100 (100 representing the highest point in the chart). Vertical lines represent the national parliamentary elections on 09/04/2006, 13/04/2008, and 24/02/2013. 
Figure 4. Percentage Point Changes in Voter Turnout by ADSL2+ Exposure (as of 24/02/2013)
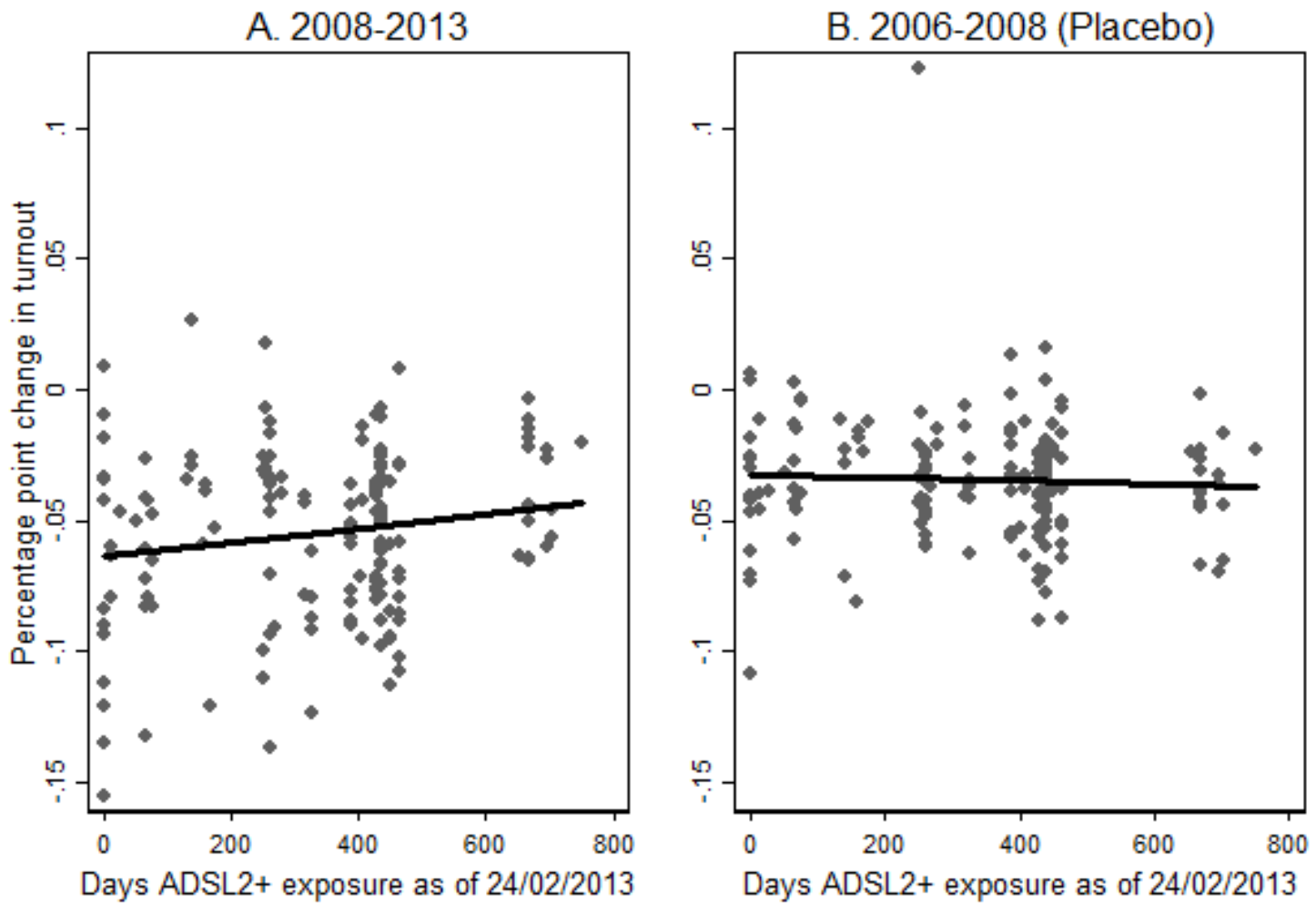

Sources: Italian Ministry of the Interior; Telecom Italia; own calculations. Notes: $N=159$ municipalities. 
Figure 5. Distribution of Municipalities with Locally Tied Candidates w.r.t. Turnout Change (2008-2013) and ADSL2+ Exposure

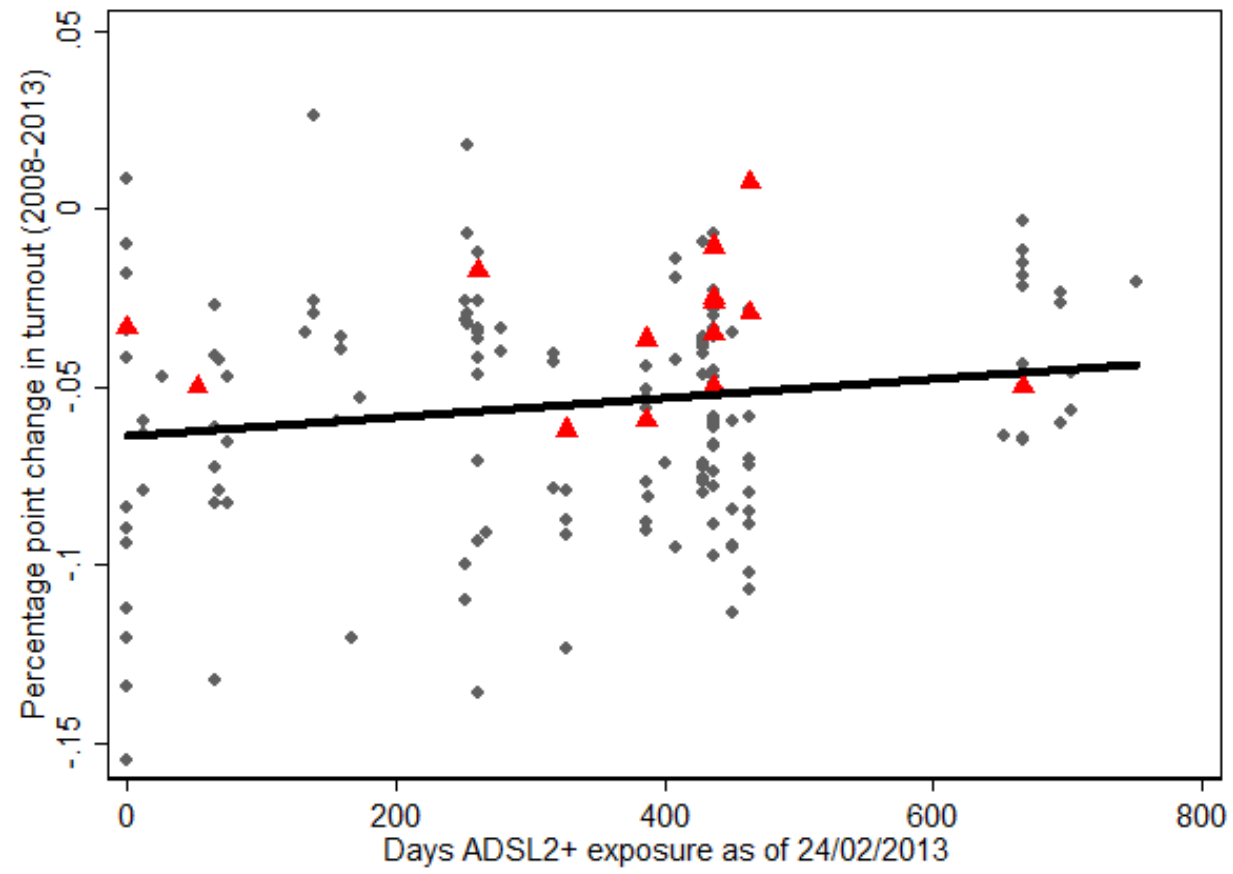

Sources: Italian Ministry of the Interior; Telecom Italia; Facebook; own calculations.

Notes: $N=159$ municipalities. Red triangles: municipalities with at least one locally tied candidate (by place of residence, birth, work, or public office). More detailed information on data collection available from the authors upon request. 
Figure 6. ADSL Subscription Rate (as of 01/03/2014) by ADSL2+ Exposure (as of 24/02/2013)

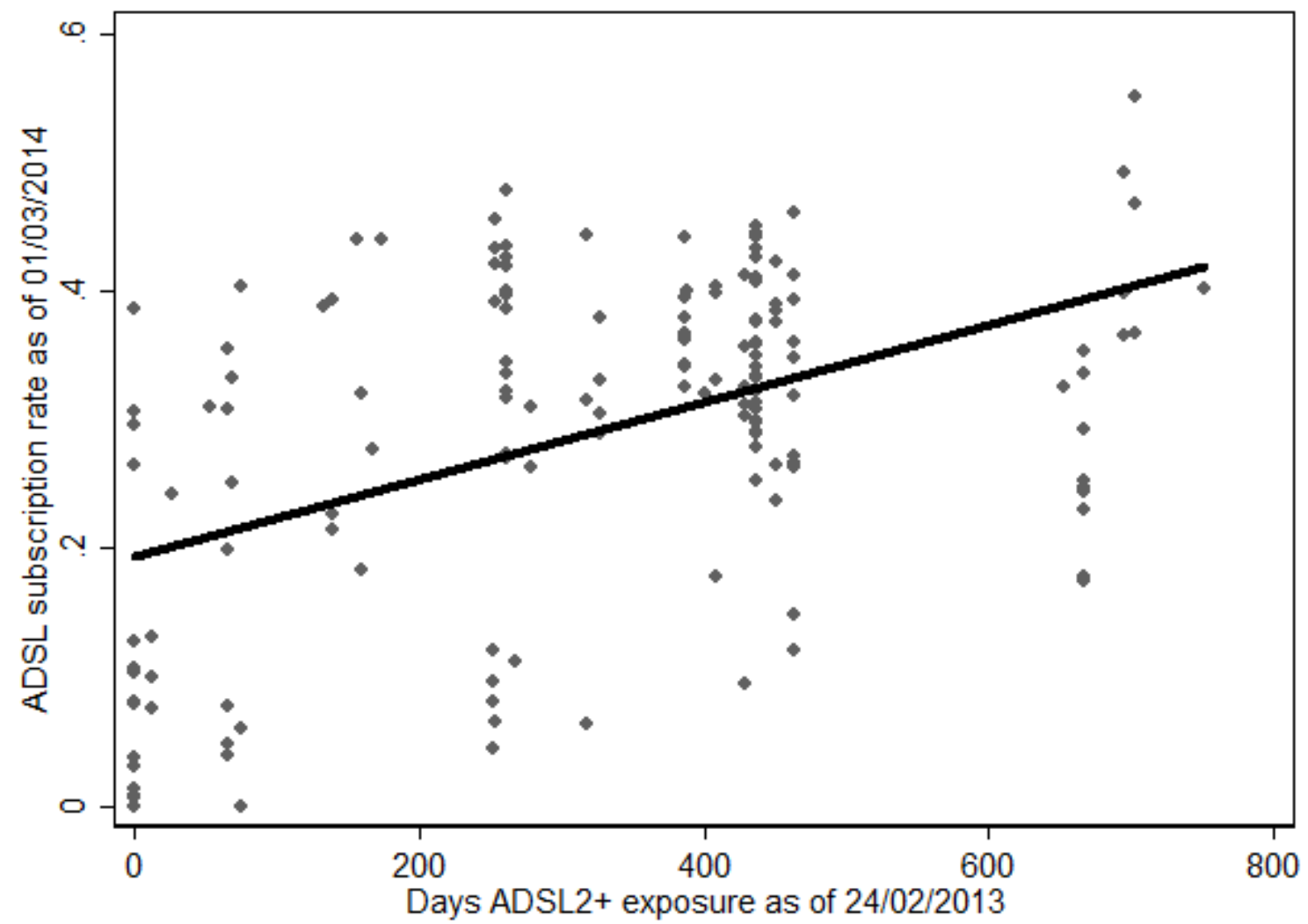

Sources: Italian Ministry of the Interior; Telecom Italia; Longitudinal Household Survey on Living Conditions in the Province of Trento; own calculations.

Notes: The ADSL subscription rate is calculated for each municipality as the sum of $7 \mathrm{Mbps}$ and $20 \mathrm{Mbps}$ subscriptions of private households with Telecom Italia (as of March 1,2014) multiplied by the average number of adults in households in municipalities targeted by the policy (2.2 in 2013), and divided by the number of eligible voters (as of February 24, 2013). Subscription data are not available for the municipalities of Fiera di Primiero, Imer, Mezzano, Siror, Tonadico, and Transacqua. $N=153$ municipalities. 
Table 1. The ADSL2+ Broadband Policy and Pre-Policy Municipality Characteristics

\begin{tabular}{|c|c|c|c|c|}
\hline & \multicolumn{2}{|c|}{$\begin{array}{c}\text { Municipalities } \\
\text { not targeted by the policy }\end{array}$} & \multicolumn{2}{|c|}{$\begin{array}{c}\text { Municipalities } \\
\text { targeted by the policy }\end{array}$} \\
\hline & Mean & SD & Mean & SD \\
\hline \multicolumn{5}{|l|}{ Demography } \\
\hline Population density 2001 & 143.47 & $(159.69)$ & 82.52 & $(231.76)$ \\
\hline Population growth rate, $10 \mathrm{yrs}$ & 0.071 & $(0.060)$ & 0.055 & $(0.078)$ \\
\hline Population share high educated 2001 & 0.334 & $(0.049)$ & 0.298 & $(0.048)$ \\
\hline Population share aged 65 and over & 0.170 & $(0.019)$ & 0.182 & $(0.037)$ \\
\hline Employment rate 2001 & 0.636 & $(0.035)$ & 0.630 & $(0.041)$ \\
\hline \multicolumn{5}{|l|}{ Industry structure } \\
\hline No. firms 2001 & 417.84 & $(1225.40)$ & 82.87 & $(83.99)$ \\
\hline Empl. growth rate, $10 \mathrm{yrs}$ & 0.128 & $(0.256)$ & 0.077 & $(0.359)$ \\
\hline Empl. share in primary sector 2001 & 0.030 & $(0.054)$ & 0.048 & $(0.115)$ \\
\hline Empl. share in manufacturing 2001 & 0.240 & $(0.158)$ & 0.212 & $(0.156)$ \\
\hline Empl. share in construction 2001 & 0.232 & $(0.125)$ & 0.244 & $(0.155)$ \\
\hline Empl. share in wholesale 2001 & 0.175 & $(0.078)$ & 0.163 & $(0.088)$ \\
\hline Empl. share in services 2001 & 0.324 & $(0.150)$ & 0.333 & $(0.178)$ \\
\hline \multicolumn{5}{|l|}{ Geography } \\
\hline Municipality's altitude (m) & 579.446 & $(307.346)$ & 746.156 & $(288.975)$ \\
\hline Distance to nearest motorway (min) & 9.147 & $(9.594)$ & 14.734 & $(11.298)$ \\
\hline \multicolumn{5}{|l|}{ Previous ADSL technology } \\
\hline Pre-policy 7Mbps & - & - & 0.665 & $(0.474)$ \\
\hline Pre-policy Lite & - & - & 0.186 & $(0.390)$ \\
\hline No. municipalities & 56 & & 167 & \\
\hline
\end{tabular}

Sources: ISTAT population \& industry census 1991 \& 2001; Atlante Statistico Comuni; Telecom Italia; own calculations. Notes: Municipality-level data. For detailed variable description, see Table A1 in the Appendix. 
Table 2. Summary Statistics

\begin{tabular}{|c|c|c|c|c|c|c|}
\hline & \multicolumn{2}{|c|}{2006} & \multicolumn{2}{|c|}{2008} & \multicolumn{2}{|c|}{2013} \\
\hline & Mean & SD & Mean & SD & Mean & SD \\
\hline \multicolumn{7}{|l|}{ Outcome variables } \\
\hline Voter turnout & 0.879 & 0.031 & 0.845 & 0.035 & 0.790 & 0.048 \\
\hline Invalid votes & 0.033 & 0.013 & 0.036 & 0.013 & 0.041 & 0.013 \\
\hline Vote share left-fringe parties & 0.081 & 0.033 & 0.069 & 0.024 & 0.030 & 0.015 \\
\hline Vote share established center-left parties & 0.298 & 0.073 & 0.296 & 0.074 & 0.198 & 0.060 \\
\hline Vote share center and liberal parties & 0.087 & 0.031 & 0.077 & 0.029 & 0.244 & 0.059 \\
\hline Vote share established center-right parties & 0.446 & 0.088 & 0.469 & 0.091 & 0.261 & 0.072 \\
\hline Vote share right-fringe parties & 0.013 & 0.010 & 0.021 & 0.009 & 0.009 & 0.007 \\
\hline Vote share other and local parties & 0.074 & 0.043 & 0.069 & 0.033 & 0.259 & 0.053 \\
\hline \multicolumn{7}{|l|}{ ADSL2+ broadband } \\
\hline Binary exposure & 0 & 0 & 0 & 0 & 0.906 & 0.293 \\
\hline No. days of exposure & 0 & 0 & 0 & 0 & 331.38 & 197.19 \\
\hline Zero exposure & 1 & 0 & 1 & 0 & 0.094 & 0.293 \\
\hline Exposure $<=6$ months & 0 & 0 & 0 & 0 & 0.157 & 0.365 \\
\hline 6 months $>$ exp. $<=12$ months & 0 & 0 & 0 & 0 & 0.208 & 0.407 \\
\hline 12 months $>$ exp. $<=18$ months & 0 & 0 & 0 & 0 & 0.434 & 0.497 \\
\hline Exposure $>18$ months & 0 & 0 & 0 & 0 & 0.107 & 0.310 \\
\hline \multicolumn{7}{|l|}{ Control variables } \\
\hline Population share female & 0.505 & 0.015 & 0.504 & 0.015 & 0.503 & 0.015 \\
\hline Population share aged 18-65 & 0.627 & 0.027 & 0.623 & 0.029 & 0.622 & 0.026 \\
\hline Population share aged 65 and over & 0.184 & 0.038 & 0.187 & 0.039 & 0.195 & 0.038 \\
\hline Share of net migration & 0.006 & 0.015 & 0.009 & 0.017 & 0.006 & 0.015 \\
\hline Share of foreigners & 0.054 & 0.035 & 0.066 & 0.039 & 0.070 & 0.041 \\
\hline Declared personal income, per capita & n.a. & n.a. & $20,487.05$ & $1,745.31$ & $20,251.42$ & $1,342.52$ \\
\hline$N$ & \multicolumn{2}{|c|}{159} & \multicolumn{2}{|c|}{159} & \multicolumn{2}{|c|}{159} \\
\hline
\end{tabular}

Sources: Italian Ministry of the Interior; Italian Ministry of Economy and Finance; ISTAT; Telecom Italia.

Notes: Party vote shares here defined as vote shares relative to the total number of valid votes. ADSL2+ broadband availability refers to the respective election dates (09/04/2006, 13/04/2008, and 24/02/2013). 
Table 3. Turnout and Invalid Votes_-Main Results and Placebo Check

\begin{tabular}{|c|c|c|c|c|}
\hline & \multicolumn{2}{|c|}{ Voter turnout } & \multicolumn{2}{|c|}{ Invalid vote } \\
\hline & (1) & (2) & (3) & (4) \\
\hline \multicolumn{5}{|l|}{ A1. Baseline (binary) } \\
\hline Binary exposure & $\begin{array}{c}0.01679 \\
(0.01345)\end{array}$ & $\begin{array}{c}0.01771 \\
(0.01164)\end{array}$ & $\begin{array}{c}0.00164 \\
(0.00431)\end{array}$ & $\begin{array}{c}0.00240 \\
(0.00482)\end{array}$ \\
\hline \multicolumn{5}{|l|}{ A2. Baseline (linear) } \\
\hline No. days of exposure/90 & $\begin{array}{l}0.00243 * \\
(0.00126)\end{array}$ & $\begin{array}{c}0.00251 * * \\
(0.00122)\end{array}$ & $\begin{array}{c}0.00008 \\
(0.00049)\end{array}$ & $\begin{array}{c}0.00039 \\
(0.00052)\end{array}$ \\
\hline \multicolumn{5}{|l|}{ A3. Baseline (categories) } \\
\hline \multicolumn{5}{|l|}{ Zero exposure (ref) } \\
\hline Exposure $<=6$ months & $\begin{array}{c}0.01383 \\
(0.01468)\end{array}$ & $\begin{array}{c}0.01135 \\
(0.01283)\end{array}$ & $\begin{array}{c}0.00126 \\
(0.00489)\end{array}$ & $\begin{array}{c}0.00119 \\
(0.00520)\end{array}$ \\
\hline 6 months $>$ exp. $<=12$ months & $\begin{array}{c}0.01785 \\
(0.01468)\end{array}$ & $\begin{array}{l}0.02275^{*} \\
(0.01262)\end{array}$ & $\begin{array}{c}0.00473 \\
(0.00460)\end{array}$ & $\begin{array}{c}0.00457 \\
(0.00511)\end{array}$ \\
\hline 12 months $>$ exp. $<=18$ months & $\begin{array}{c}0.01348 \\
(0.01367)\end{array}$ & $\begin{array}{c}0.01342 \\
(0.01186)\end{array}$ & $\begin{array}{c}-0.00014 \\
(0.00461)\end{array}$ & $\begin{array}{c}0.00100 \\
(0.00516)\end{array}$ \\
\hline Exposure $>18$ months & $\begin{array}{c}0.03253 * * \\
(0.01417)\end{array}$ & $\begin{array}{c}0.03251 * * * \\
(0.01222)\end{array}$ & $\begin{array}{c}0.00339 \\
(0.00504)\end{array}$ & $\begin{array}{c}0.00498 \\
(0.00542)\end{array}$ \\
\hline \multicolumn{5}{|l|}{ B1. Placebo (binary) } \\
\hline Binary exposure & $\begin{array}{c}0.00614 \\
(0.00771)\end{array}$ & $\begin{array}{c}0.00755 \\
(0.00760)\end{array}$ & $\begin{array}{c}0.00353 \\
(0.00233)\end{array}$ & $\begin{array}{c}0.00346 \\
(0.00231)\end{array}$ \\
\hline \multicolumn{5}{|l|}{ B2. Placebo (linear) } \\
\hline No. days of exposure/90 & $\begin{array}{l}-0.00061 \\
(0.00084)\end{array}$ & $\begin{array}{l}-0.00032 \\
(0.00083)\end{array}$ & $\begin{array}{c}0.00055 \\
(0.00034)\end{array}$ & $\begin{array}{c}0.00045 \\
(0.00040)\end{array}$ \\
\hline \multicolumn{5}{|l|}{ B3. Placebo (categories) } \\
\hline \multicolumn{5}{|l|}{ Zero exposure (ref) } \\
\hline Exposure $<=6$ months & $\begin{array}{c}0.01053 \\
(0.00856)\end{array}$ & $\begin{array}{c}0.01066 \\
(0.00869)\end{array}$ & $\begin{array}{c}0.00058 \\
(0.00285)\end{array}$ & $\begin{array}{c}0.00127 \\
(0.00268)\end{array}$ \\
\hline 6 months $>$ exp. $<=12$ months & $\begin{array}{c}0.00903 \\
(0.00921)\end{array}$ & $\begin{array}{c}0.01055 \\
(0.00911)\end{array}$ & $\begin{array}{c}0.00406 \\
(0.00264)\end{array}$ & $\begin{array}{c}0.00391 \\
(0.00263)\end{array}$ \\
\hline 12 months $>$ exp. $<=18$ months & $\begin{array}{c}0.00389 \\
(0.00793)\end{array}$ & $\begin{array}{c}0.00495 \\
(0.00779)\end{array}$ & $\begin{array}{c}0.00440 \\
(0.00268)\end{array}$ & $\begin{array}{c}0.00436 \\
(0.00283)\end{array}$ \\
\hline Exposure $>18$ months & $\begin{array}{c}0.00315 \\
(0.00867)\end{array}$ & $\begin{array}{c}0.00573 \\
(0.00850)\end{array}$ & $\begin{array}{c}0.00336 \\
(0.00308)\end{array}$ & $\begin{array}{c}0.00285 \\
(0.00323)\end{array}$ \\
\hline Control variables & no & yes & no & yes \\
\hline$N$ & 318 & 318 & 318 & 318 \\
\hline No. of municipalities & 159 & 159 & 159 & 159 \\
\hline $\begin{array}{l}\text { Sources: Baseline-2008 \& } 201 \\
\text { of Economy and Finance; Telec } \\
\text { Notes: Each panel A1-B3 shov } \\
\text { fixed effects, year indicator, an } \\
2 \text { and } 4 \text { additionally control for } \\
\text { share, share of population age } \\
\text { foreigners. Panels A1-A3 of C } \\
\text { this information is not availab } \\
\text { (Panels B1 and B2 of Columns } \\
\text { eligible voters. Invalid vote is th }\end{array}$ & $\begin{array}{l}-2006 \& 20 \\
\text { nts from sep } \\
\text { term. Robus } \\
\text { ng municipal } \\
\text { share of pop } \\
\text { d } 4 \text { also cont } \\
\text { ear } 2006 \text {; he } \\
\text { ter turnout i } \\
\text { f null or whit }\end{array}$ & $\begin{array}{l}\text { Italian Ministry } \\
\text { e regressions. } \\
\text { indard errors in } \\
\text { haracteristics: } \\
\text { ion older than } \\
\text { for declared pe } \\
\text { this control is } \\
\text { culated as tota } \\
\text { tes over numb }\end{array}$ & $\begin{array}{l}\text { Interior; IST } \\
\text { nations cont } \\
\text { leses. Specif } \\
\text { ion size (log) } \\
\text { t migration } \\
\text { acome (per c } \\
\text { cluded in th } \\
\text { valid or inva } \\
\text { sible voters. }\end{array}$ & $\begin{array}{l}\text { Italian Ministry } \\
\text { or municipality } \\
\text { ons in Columns } \\
\text { nale population } \\
\text { and share of } \\
\text {, log), whereas } \\
\text { cebo estimates } \\
\text { over number of }\end{array}$ \\
\hline
\end{tabular}


Table 4. Party Vote Shares

\begin{tabular}{|c|c|c|c|c|c|c|c|c|c|c|c|c|}
\hline & \multicolumn{2}{|c|}{ Left-fringe } & \multicolumn{2}{|c|}{ Established center-left } & \multicolumn{2}{|c|}{ Center and liberal } & \multicolumn{2}{|c|}{ Established center-right } & \multicolumn{2}{|c|}{ Right-fringe } & \multicolumn{2}{|c|}{ Others and local } \\
\hline & (1) & (2) & (3) & (4) & (5) & (6) & (7) & (8) & (9) & (10) & (11) & (12) \\
\hline \multicolumn{13}{|l|}{ A1. Baseline (binary) } \\
\hline Binary exposure & $\begin{array}{c}0.0015 \\
(0.0063)\end{array}$ & $\begin{array}{c}0.0030 \\
(0.0062)\end{array}$ & $\begin{array}{c}0.0408 * * \\
(0.0167)\end{array}$ & $\begin{array}{c}0.0366^{* *} \\
(0.0154)\end{array}$ & $\begin{array}{l}-0.0091 \\
(0.0200)\end{array}$ & $\begin{array}{c}0.0002 \\
(0.0188)\end{array}$ & $\begin{array}{c}-0.0331^{* *} \\
(0.0136)\end{array}$ & $\begin{array}{l}-0.0244^{*} \\
(0.0136)\end{array}$ & $\begin{array}{c}0.0046^{*} \\
(0.0025)\end{array}$ & $\begin{array}{c}0.0047 * * \\
(0.0022)\end{array}$ & $\begin{array}{l}-0.0047 \\
(0.0155)\end{array}$ & $\begin{array}{l}-0.0201 \\
(0.0145)\end{array}$ \\
\hline \multicolumn{13}{|l|}{ A2. Baseline (linear) } \\
\hline No. days of exposure/90 & $\begin{array}{l}-0.0004 \\
(0.0009)\end{array}$ & $\begin{array}{c}0.0001 \\
(0.0008)\end{array}$ & $\begin{array}{c}0.0016 \\
(0.0020)\end{array}$ & $\begin{array}{c}0.0008 \\
(0.0018)\end{array}$ & $\begin{array}{l}-0.0013 \\
(0.0024)\end{array}$ & $\begin{array}{c}0.0001 \\
(0.0020)\end{array}$ & $\begin{array}{l}-0.0006 \\
(0.0023)\end{array}$ & $\begin{array}{l}-0.0003 \\
(0.0020)\end{array}$ & $\begin{array}{l}-0.0002 \\
(0.0003)\end{array}$ & $\begin{array}{l}-0.0002 \\
(0.0003)\end{array}$ & $\begin{array}{c}0.0010 \\
(0.0020)\end{array}$ & $\begin{array}{l}-0.0005 \\
(0.0019)\end{array}$ \\
\hline \multicolumn{13}{|l|}{ A3. Baseline (categories) } \\
\hline $\begin{array}{l}\text { Zero exposure (ref) } \\
\text { Exposure }<=6 \text { months }\end{array}$ & $\begin{array}{c}0.0071 \\
(0.0075)\end{array}$ & $\begin{array}{c}0.0065 \\
(0.0072)\end{array}$ & $\begin{array}{l}0.0447 * * \\
(0.0180)\end{array}$ & $\begin{array}{l}0.0436 * * \\
(0.0172)\end{array}$ & $\begin{array}{c}0.0029 \\
(0.0231)\end{array}$ & $\begin{array}{c}0.0064 \\
(0.0236)\end{array}$ & $\begin{array}{l}-0.0325^{*} \\
(0.0174)\end{array}$ & $\begin{array}{l}-0.0287 \\
(0.0182)\end{array}$ & $\begin{array}{l}0.0061 * * \\
(0.0030)\end{array}$ & $\begin{array}{l}0.0067 * * \\
(0.0028)\end{array}$ & $\begin{array}{l}-0.0282 \\
(0.0179)\end{array}$ & $\begin{array}{r}-0.0345^{* *} \\
(0.0166)\end{array}$ \\
\hline 6 months $>$ exp. $<=12$ months & -0.0013 & -0.0006 & $0.0450^{* *}$ & $0.0412 * *$ & -0.0199 & -0.0128 & $-0.0402^{* *}$ & $-0.0280^{*}$ & $0.0061 * *$ & $0.0051^{* *}$ & 0.0103 & -0.0049 \\
\hline 12 months $>$ exp. $<=18$ months & $\begin{array}{c}(0.0068) \\
0.0012\end{array}$ & $\begin{array}{c}(0.0072) \\
0.0026\end{array}$ & $\begin{array}{l}(0.0178) \\
0.0410 * *\end{array}$ & $\begin{array}{l}(0.0168) \\
0.0327 * *\end{array}$ & $\begin{array}{l}(0.0207) \\
-0.0069\end{array}$ & $\begin{array}{c}(0.0191) \\
0.0060\end{array}$ & $\begin{array}{c}(0.0155) \\
-0.0376^{* * *}\end{array}$ & $\begin{array}{l}(0.0156) \\
-0.0254^{*}\end{array}$ & $\begin{array}{c}(0.0028) \\
0.0039\end{array}$ & $\begin{array}{l}(0.0025) \\
0.0045^{*}\end{array}$ & $\begin{array}{l}(0.0169) \\
-0.0015\end{array}$ & $\begin{array}{l}(0.0160) \\
-0.0204\end{array}$ \\
\hline Exposure $>18$ months & $\begin{array}{l}(0.0066) \\
-0.0002\end{array}$ & $\begin{array}{c}(0.0066) \\
0.0037\end{array}$ & $\begin{array}{c}(0.0172) \\
0.0266\end{array}$ & $\begin{array}{c}(0.0156) \\
0.0281\end{array}$ & $\begin{array}{l}(0.0205) \\
-0.0147\end{array}$ & $\begin{array}{c}(0.0186) \\
-0.0063\end{array}$ & $\begin{array}{c}(0.0140) \\
-0.0017\end{array}$ & $\begin{array}{c}(0.0134) \\
-0.0087\end{array}$ & $\begin{array}{c}(0.0027) \\
0.0022\end{array}$ & $\begin{array}{c}(0.0024) \\
0.0012\end{array}$ & $\begin{array}{l}(0.0161) \\
-0.0122\end{array}$ & $\begin{array}{l}(0.0152) \\
-0.0181\end{array}$ \\
\hline & $(0.0087)$ & $(0.0082)$ & $(0.0213)$ & $(0.0184)$ & $(0.0258)$ & $(0.0220)$ & $(0.0224)$ & $(0.0193)$ & $(0.0029)$ & $(0.0028)$ & $(0.0210)$ & $(0.0191)$ \\
\hline Control variables & no & yes & no & yes & no & yes & no & yes & no & yes & no & yes \\
\hline $\begin{array}{l}N \\
\text { No. of municipalities }\end{array}$ & $\begin{array}{l}318 \\
159\end{array}$ & $\begin{array}{l}318 \\
159\end{array}$ & $\begin{array}{l}318 \\
159\end{array}$ & $\begin{array}{l}318 \\
159\end{array}$ & $\begin{array}{l}318 \\
159\end{array}$ & $\begin{array}{l}318 \\
159\end{array}$ & $\begin{array}{l}318 \\
159\end{array}$ & $\begin{array}{l}318 \\
159\end{array}$ & $\begin{array}{l}318 \\
159\end{array}$ & $\begin{array}{l}318 \\
159\end{array}$ & $\begin{array}{l}318 \\
159\end{array}$ & $\begin{array}{l}318 \\
159\end{array}$ \\
\hline
\end{tabular}

Sources: 2008 \& 2013, Italian Ministry of the Interior; Italian Ministry of Economy and Finance; ISTAT; Telecom Italia.

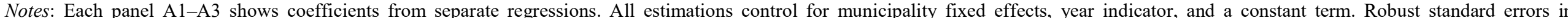

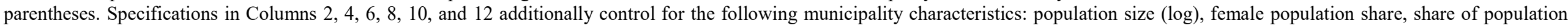

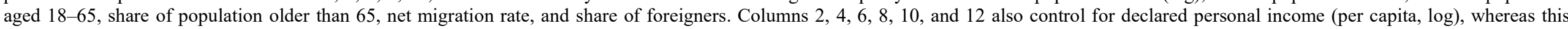

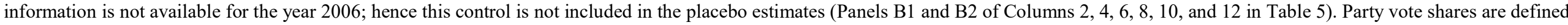
as vote shares relative to the total number of valid votes. Party classification is described in Table A2 in the Appendix. 
Table 5. Party Vote Shares-Placebo Check

\begin{tabular}{|c|c|c|c|c|c|c|c|c|c|c|c|c|}
\hline & \multicolumn{2}{|c|}{ Left-fringe } & \multicolumn{2}{|c|}{ Established center-left } & \multicolumn{2}{|c|}{ Center and liberal } & \multicolumn{2}{|c|}{ Established center-right } & \multicolumn{2}{|c|}{ Right-fringe } & \multicolumn{2}{|c|}{ Others and local } \\
\hline & (1) & (2) & (3) & (4) & (5) & (6) & (7) & (8) & (9) & $(10)$ & (11) & (12) \\
\hline $\begin{array}{l}\text { B1. Placebo (binary) } \\
\text { Binary exposure }\end{array}$ & $\begin{array}{c}0.0033 \\
(0.0081)\end{array}$ & $\begin{array}{c}0.0051 \\
(0.0074)\end{array}$ & $\begin{array}{c}0.0174 \\
(0.0137)\end{array}$ & $\begin{array}{c}0.0158 \\
(0.0134)\end{array}$ & $\begin{array}{l}-0.0095 \\
(0.0088)\end{array}$ & $\begin{array}{l}-0.0094 \\
(0.0095)\end{array}$ & $\begin{array}{l}-0.0052 \\
(0.0099)\end{array}$ & $\begin{array}{l}-0.0067 \\
(0.0100)\end{array}$ & $\begin{array}{l}-0.0026 \\
(0.0024)\end{array}$ & $\begin{array}{l}-0.0018 \\
(0.0026)\end{array}$ & $\begin{array}{l}-0.0035 \\
(0.0078)\end{array}$ & $\begin{array}{l}-0.0030 \\
(0.0073)\end{array}$ \\
\hline $\begin{array}{l}\text { B2. Placebo (linear) } \\
\text { No. days of exposure/90 }\end{array}$ & $\begin{array}{c}0.0005 \\
(0.0008)\end{array}$ & $\begin{array}{c}0.0009 \\
(0.0008)\end{array}$ & $\begin{array}{c}0.0013 \\
(0.0015)\end{array}$ & $\begin{array}{c}0.0011 \\
(0.0014)\end{array}$ & $\begin{array}{l}-0.0014 \\
(0.0014)\end{array}$ & $\begin{array}{l}-0.0013 \\
(0.0012)\end{array}$ & $\begin{array}{l}-0.0010 \\
(0.0013)\end{array}$ & $\begin{array}{l}-0.0013 \\
(0.0013)\end{array}$ & $\begin{array}{l}-0.0007 \\
(0.0005)\end{array}$ & $\begin{array}{l}-0.0006 \\
(0.0004)\end{array}$ & $\begin{array}{c}0.0013 \\
(0.0009)\end{array}$ & $\begin{array}{c}0.0013 \\
(0.0009)\end{array}$ \\
\hline B3. Placebo (categories) & & & & & & & & & & & & \\
\hline $\begin{array}{l}\text { Zero exposure (ref) } \\
\text { Exposure }<=6 \text { months }\end{array}$ & $\begin{array}{c}-0.0019 \\
(0.0088) \\
0.0085\end{array}$ & $\begin{array}{c}-0.0010 \\
(0.0081) \\
0.0093\end{array}$ & $\begin{array}{c}0.0119 \\
(0.0163) \\
0.0246 *\end{array}$ & $\begin{array}{c}0.0112 \\
(0.0165) \\
0.0229\end{array}$ & $\begin{array}{l}-0.0027 \\
(0.0118) \\
-0.0108\end{array}$ & $\begin{array}{l}-0.0040 \\
(0.0125)\end{array}$ & $\begin{array}{c}0.0049 \\
(0.0115)\end{array}$ & $\begin{array}{c}0.0043 \\
(0.0117)\end{array}$ & $\begin{array}{c}-0.0009 \\
(0.0028)\end{array}$ & $\begin{array}{l}-0.0004 \\
(0.0029)\end{array}$ & $\begin{array}{l}-0.0113 \\
(0.0092)\end{array}$ & $\begin{array}{l}-0.0101 \\
(0.0087)\end{array}$ \\
\hline 12 months $>$ exp. $<=18$ months & $\begin{array}{c}0.0085 \\
(0.0084) \\
0.0024\end{array}$ & $\begin{array}{c}0.0093 \\
(0.0078) \\
0.0051\end{array}$ & $\begin{array}{c}0.0240 \\
(0.0145) \\
0.0163\end{array}$ & $\begin{array}{c}0.0229 \\
(0.0139) \\
0.0142\end{array}$ & $\begin{array}{c}-0.0100 \\
(0.0093) \\
-0.0120\end{array}$ & $\begin{array}{c}-0.0108 \\
(0.0101) \\
-0.0117\end{array}$ & $\begin{array}{c}-0.00 / 0 \\
(0.0108) \\
-0.0080\end{array}$ & $\begin{array}{c}-0.0085 \\
(0.0108) \\
-0.0109\end{array}$ & $\begin{array}{c}-0.001 / \\
(0.0027) \\
-0.0021\end{array}$ & $\begin{array}{c}-0.0012 \\
(0.0029) \\
-0.0014\end{array}$ & $\begin{array}{c}-0.0150 \\
(0.0104) \\
0.0035\end{array}$ & $\begin{array}{c}(0.0098) \\
0.0048\end{array}$ \\
\hline Exposure $>18$ months & $\begin{array}{c}(0.0084) \\
0.0043\end{array}$ & $\begin{array}{c}(0.0076) \\
0.0069\end{array}$ & $\begin{array}{c}(0.0139) \\
0.0164\end{array}$ & $\begin{array}{c}(0.0136) \\
0.0147\end{array}$ & $\begin{array}{l}(0.0090) \\
-0.0064\end{array}$ & $\begin{array}{l}(0.0097) \\
-0.0069\end{array}$ & $\begin{array}{l}(0.0103) \\
-0.0041\end{array}$ & $\begin{array}{l}(0.0105) \\
-0.0060\end{array}$ & $\begin{array}{l}(0.0026) \\
-0.0087^{*}\end{array}$ & $\begin{array}{l}(0.0028) \\
-0.0073 *\end{array}$ & $\begin{array}{l}(0.0078) \\
-0.0015\end{array}$ & $\begin{array}{c}(0.0077) \\
-0.0014\end{array}$ \\
\hline & $(0.0090)$ & $(0.0086)$ & $(0.0153)$ & $(0.0149)$ & $(0.0138)$ & $(0.0124)$ & $(0.0143)$ & $(0.0135)$ & $(0.0049)$ & $(0.0042)$ & $(0.0085)$ & $(0.0087)$ \\
\hline Control variables & no & yes & no & yes & no & yes & no & yes & no & yes & no & yes \\
\hline$N$ & 318 & 318 & 318 & 318 & 318 & 318 & 318 & 318 & 318 & 318 & 318 & 318 \\
\hline No. of municipalities & 159 & 159 & 159 & 159 & 159 & 159 & 159 & 159 & 159 & 159 & 159 & 159 \\
\hline
\end{tabular}

Sources: 2006 \& 2008, Italian Ministry of the Interior; Italian Ministry of Economy and Finance; ISTAT; Telecom Italia.

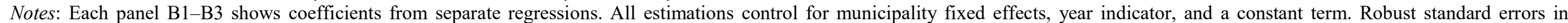

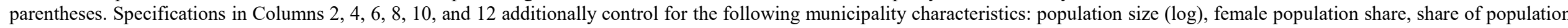

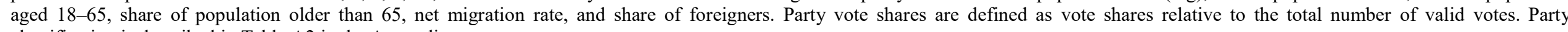
classification is described in Table A2 in the Appendix. 
Table 6. Party Vote Shares-Votes per Eligible Voters

\begin{tabular}{|c|c|c|c|c|c|c|c|c|c|c|c|c|}
\hline & \multicolumn{2}{|c|}{ Left-fringe } & \multicolumn{2}{|c|}{ Established center-left } & \multicolumn{2}{|c|}{ Center and liberal } & \multicolumn{2}{|c|}{ Established center-right } & \multicolumn{2}{|c|}{ Right-fringe } & \multicolumn{2}{|c|}{ Others and local } \\
\hline & (1) & (2) & (3) & (4) & (5) & (6) & (7) & (8) & (9) & $(10)$ & (11) & (12) \\
\hline \multicolumn{13}{|l|}{ A1. Baseline (binary) } \\
\hline Binary exposure & $\begin{array}{c}0.0010 \\
(0.0054)\end{array}$ & $\begin{array}{c}0.0025 \\
(0.0052)\end{array}$ & $\begin{array}{l}0.0322 * * \\
(0.0150)\end{array}$ & $\begin{array}{c}0.0290 * * \\
(0.0140)\end{array}$ & $\begin{array}{c}0.0007 \\
(0.0162)\end{array}$ & $\begin{array}{c}0.0069 \\
(0.0154)\end{array}$ & $\begin{array}{c}-0.0311 * * * \\
(0.0108)\end{array}$ & $\begin{array}{c}-0.0222 * * \\
(0.0110)\end{array}$ & $\begin{array}{l}0.0031 * \\
(0.0018)\end{array}$ & $\begin{array}{c}0.0033 * * \\
(0.0016)\end{array}$ & $\begin{array}{c}0.0093 \\
(0.0128)\end{array}$ & $\begin{array}{l}-0.0042 \\
(0.0116)\end{array}$ \\
\hline \multicolumn{13}{|l|}{ A2. Baseline (linear) } \\
\hline No. days of exposure/90 & $\begin{array}{l}-0.0004 \\
(0.0007)\end{array}$ & $\begin{array}{c}0.00005 \\
(0.00068)\end{array}$ & $\begin{array}{c}0.0013 \\
(0.0017)\end{array}$ & $\begin{array}{c}0.0007 \\
(0.0016)\end{array}$ & $\begin{array}{l}-0.0001 \\
(0.0019)\end{array}$ & $\begin{array}{c}0.0008 \\
(0.0016)\end{array}$ & $\begin{array}{l}-0.0005 \\
(0.0020)\end{array}$ & $\begin{array}{c}0.00002 \\
(0.00172)\end{array}$ & $\begin{array}{l}-0.0002 \\
(0.0003)\end{array}$ & $\begin{array}{l}-0.0002 \\
(0.0003)\end{array}$ & $\begin{array}{c}0.0022 \\
(0.0016)\end{array}$ & $\begin{array}{c}0.0007 \\
(0.0014)\end{array}$ \\
\hline \multicolumn{13}{|l|}{ A3. Baseline (categories) } \\
\hline $\begin{array}{l}\text { Zero exposure (ref) } \\
\text { Exposure }<=6 \text { months }\end{array}$ & $\begin{array}{c}0.0057 \\
(0.0063)\end{array}$ & $\begin{array}{c}0.0053 \\
(0.0060)\end{array}$ & $\begin{array}{c}0.0351 * * \\
(0.0158)\end{array}$ & $\begin{array}{c}0.0338^{* *} \\
(0.0149)\end{array}$ & $\begin{array}{c}0.0090 \\
(0.0185)\end{array}$ & $\begin{array}{c}0.0109 \\
(0.0193)\end{array}$ & $\begin{array}{c}-0.0314^{* *} \\
(0.0143)\end{array}$ & $\begin{array}{c}-0.0288^{*} \\
(0.0151)\end{array}$ & $\begin{array}{l}0.0043 * \\
(0.0022)\end{array}$ & $\begin{array}{c}0.0048^{* *} \\
(0.0021)\end{array}$ & $\begin{array}{c}-0.0102 \\
(0.0146)\end{array}$ & $\begin{array}{c}0.0057 \\
(0.0063)\end{array}$ \\
\hline 6 months $>$ exp. $<=12$ months & $\begin{array}{l}-0.0016 \\
(0.0058)\end{array}$ & $\begin{array}{l}-0.0004 \\
(0.0060)\end{array}$ & $\begin{array}{c}0.0338 * * \\
(0.0159)\end{array}$ & $\begin{array}{l}0.0320 * * \\
(0.0151)\end{array}$ & $\begin{array}{l}-0.0075 \\
(0.0166)\end{array}$ & $\begin{array}{l}-0.0020 \\
(0.0154)\end{array}$ & $\begin{array}{c}-0.0370 * * * \\
(0.0126)\end{array}$ & $\begin{array}{l}-0.0235^{*} \\
(0.0129)\end{array}$ & $\begin{array}{c}0.0042 * * \\
(0.0020)\end{array}$ & $\begin{array}{l}0.0037^{*} \\
(0.0019)\end{array}$ & $\begin{array}{c}0.0210 \\
(0.0140)\end{array}$ & $\begin{array}{l}-0.0016 \\
(0.0058)\end{array}$ \\
\hline 12 months $>$ exp. $<=18$ months & $\begin{array}{c}0.0011 \\
(0.0056)\end{array}$ & $\begin{array}{c}0.0025 \\
(0.0055)\end{array}$ & $\begin{array}{c}0.0332 * * \\
(0.0153)\end{array}$ & $\begin{array}{l}0.0269^{*} \\
(0.0142)\end{array}$ & $\begin{array}{c}0.0013 \\
(0.0165)\end{array}$ & $\begin{array}{c}0.0095 \\
(0.0150)\end{array}$ & $\begin{array}{c}-0.0351^{* * *} \\
(0.0113)\end{array}$ & $\begin{array}{c}-0.0229^{* *} \\
(0.0111)\end{array}$ & $\begin{array}{c}0.0025 \\
(0.0020)\end{array}$ & $\begin{array}{l}0.0032^{*} \\
(0.0018)\end{array}$ & $\begin{array}{c}0.0107 \\
(0.0133)\end{array}$ & $\begin{array}{c}0.0011 \\
(0.0056)\end{array}$ \\
\hline Exposure $>18$ months & $\begin{array}{l}-0.0010 \\
(0.0074)\end{array}$ & $\begin{array}{c}0.0022 \\
(0.0069)\end{array}$ & $\begin{array}{c}0.0205 \\
(0.0186)\end{array}$ & $\begin{array}{c}0.0222 \\
(0.0164)\end{array}$ & $\begin{array}{c}0.0016 \\
(0.0211)\end{array}$ & $\begin{array}{c}0.0065 \\
(0.0180)\end{array}$ & $\begin{array}{l}-0.0028 \\
(0.0190)\end{array}$ & $\begin{array}{l}-0.0070 \\
(0.0162)\end{array}$ & $\begin{array}{c}0.0012 \\
(0.0022)\end{array}$ & $\begin{array}{c}0.0005 \\
(0.0022)\end{array}$ & $\begin{array}{c}0.0096 \\
(0.0168)\end{array}$ & $\begin{array}{l}-0.0010 \\
(0.0074)\end{array}$ \\
\hline Control variables & no & yes & no & yes & no & yes & no & yes & no & yes & no & yes \\
\hline$N$ & 318 & 318 & 318 & 318 & 318 & 318 & 318 & 318 & 318 & 318 & 318 & 318 \\
\hline No. of municipalities & 159 & 159 & 159 & 159 & 159 & 159 & 159 & 159 & 159 & 159 & 159 & 159 \\
\hline
\end{tabular}

Sources: 2008 \& 2013, Italian Ministry of the Interior; Italian Ministry of Economy and Finance; ISTAT; Telecom Italia.

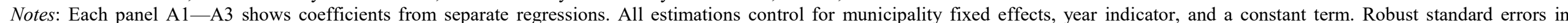

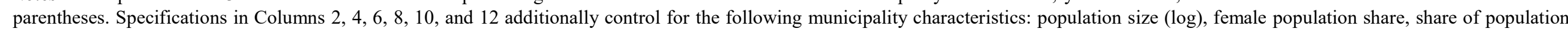

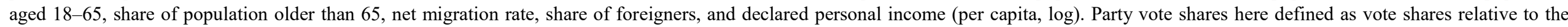
total number of eligible voters. Party classification is described in Table A2 in the Appendix. 
Table 7. Vote Shares for Movimento 5 Stelle and Fare per Fermare il Declino

\begin{tabular}{|c|c|c|c|c|}
\hline & \multicolumn{2}{|c|}{ Movimento 5 Stelle } & \multicolumn{2}{|c|}{ Fare per Fermare il Declino } \\
\hline & (1) & (2) & (3) & (4) \\
\hline \multicolumn{5}{|l|}{ A1. Baseline (binary) } \\
\hline Binary exposure & $\begin{array}{l}-0.0046 \\
(0.0123)\end{array}$ & $\begin{array}{l}-0.0178 \\
(0.0129)\end{array}$ & $\begin{array}{c}0.0027 \\
(0.0020)\end{array}$ & $\begin{array}{c}0.0020 \\
(0.0020)\end{array}$ \\
\hline \multicolumn{5}{|l|}{ A2. Baseline (linear) } \\
\hline No. days of exposure/90 & $\begin{array}{c}0.0015 \\
(0.0016)\end{array}$ & $\begin{array}{c}0.0001 \\
(0.0015)\end{array}$ & $\begin{array}{c}0.0006 * * \\
(0.0002)\end{array}$ & $\begin{array}{c}0.0004 * \\
(0.0002)\end{array}$ \\
\hline \multicolumn{5}{|l|}{ A3. Baseline (categories) } \\
\hline \multicolumn{5}{|l|}{ Zero exposure (ref) } \\
\hline Exposure $<=6$ months & $\begin{array}{c}-0.0299 * * \\
(0.0142)\end{array}$ & $\begin{array}{c}-0.0347 * * \\
(0.0142)\end{array}$ & $\begin{array}{c}-0.00002 \\
(0.00224)\end{array}$ & $\begin{array}{c}0.0003 \\
(0.0023)\end{array}$ \\
\hline 6 months $>$ exp. $<=12$ months & $\begin{array}{c}0.0114 \\
(0.0136)\end{array}$ & $\begin{array}{c}-0.0014 \\
(0.0143)\end{array}$ & $\begin{array}{c}0.0034 \\
(0.0022)\end{array}$ & $\begin{array}{c}0.0024 \\
(0.0022)\end{array}$ \\
\hline 12 months $>$ exp. $<=18$ months & $\begin{array}{l}-0.0029 \\
(0.0129)\end{array}$ & $\begin{array}{c}-0.0195 \\
(0.0133)\end{array}$ & $\begin{array}{c}0.0032 \\
(0.0021)\end{array}$ & $\begin{array}{c}0.0025 \\
(0.0022)\end{array}$ \\
\hline Exposure $>18$ months & $\begin{array}{c}-0.0053 \\
(0.0161)\end{array}$ & $\begin{array}{c}-0.0094 \\
(0.0157)\end{array}$ & $\begin{array}{c}0.0035 \\
(0.0026)\end{array}$ & $\begin{array}{c}0.0030 \\
(0.0024)\end{array}$ \\
\hline Control variables & no & yes & no & yes \\
\hline$N$ & 318 & 318 & 318 & 318 \\
\hline No. of municipalities & 159 & 159 & 159 & 159 \\
\hline
\end{tabular}


Table 8. Placebo Analysis w.r.t. Socioeconomic Municipality Characteristics

\begin{tabular}{|c|c|c|c|c|c|}
\hline & $\begin{array}{l}\text { Female } \\
\text { population } \\
\text { share }\end{array}$ & $\begin{array}{c}\text { Share of } \\
\text { population } \\
\text { aged } 18-65\end{array}$ & $\begin{array}{l}\text { Share of } \\
\text { population } \\
\text { aged more } \\
\text { than } 65 \\
\end{array}$ & $\begin{array}{l}\text { Share of net } \\
\text { migration }\end{array}$ & $\begin{array}{l}\text { Share of } \\
\text { foreigners }\end{array}$ \\
\hline & (1) & (2) & (3) & (4) & (5) \\
\hline \multicolumn{6}{|l|}{ B1. Placebo (binary) } \\
\hline Binary exposure & $\begin{array}{l}0.0026^{*} \\
(0.0013)\end{array}$ & $\begin{array}{c}0.0006 \\
(0.0043)\end{array}$ & $\begin{array}{c}0.0003 \\
(0.0031)\end{array}$ & $\begin{array}{c}0.0011 \\
(0.0039)\end{array}$ & $\begin{array}{c}0.0004 \\
(0.0039)\end{array}$ \\
\hline \multicolumn{6}{|l|}{ B2. Placebo (linear) } \\
\hline No. days of exposure/90 & $\begin{array}{c}0.0004 \\
(0.0002)\end{array}$ & $\begin{array}{l}-0.0003 \\
(0.0005)\end{array}$ & $\begin{array}{c}0.0000 \\
(0.0003)\end{array}$ & $\begin{array}{l}-0.0006 \\
(0.0005)\end{array}$ & $\begin{array}{l}-0.0002 \\
(0.0005)\end{array}$ \\
\hline \multicolumn{6}{|l|}{ B3. Placebo (categories) } \\
\hline $\begin{array}{l}\text { Zero exposure (ref) } \\
\text { Exposure }<=6 \text { months }\end{array}$ & $\begin{array}{c}0.0021 \\
(0.0018)\end{array}$ & $\begin{array}{c}0.0028 \\
(0.0046)\end{array}$ & $\begin{array}{l}-0.0007 \\
(0.0035)\end{array}$ & $\begin{array}{c}0.0046 \\
(0.0045)\end{array}$ & $\begin{array}{c}0.0018 \\
(0.0043)\end{array}$ \\
\hline 6 months $>$ exp. $<=12$ months & $\begin{array}{c}0.0022 \\
(0.0015)\end{array}$ & $\begin{array}{c}0.0001 \\
(0.0047)\end{array}$ & $\begin{array}{c}0.0020 \\
(0.0032)\end{array}$ & $\begin{array}{c}0.0008 \\
(0.0042)\end{array}$ & $\begin{array}{c}0.0010 \\
(0.0041)\end{array}$ \\
\hline 12 months $>$ exp. $<=18$ months & $\begin{array}{l}0.0028 * \\
(0.0015)\end{array}$ & $\begin{array}{c}0.0010 \\
(0.0043)\end{array}$ & $\begin{array}{l}-0.0001 \\
(0.0031)\end{array}$ & $\begin{array}{c}0.0010 \\
(0.0040)\end{array}$ & $\begin{array}{l}-0.0007 \\
(0.0041)\end{array}$ \\
\hline Exposure $>18$ months & $\begin{array}{c}0.0031 \\
(0.0022)\end{array}$ & $\begin{array}{l}-0.0035 \\
(0.0050)\end{array}$ & $\begin{array}{c}0.0000 \\
(0.0034)\end{array}$ & $\begin{array}{l}-0.0046 \\
(0.0045)\end{array}$ & $\begin{array}{c}0.0012 \\
(0.0053)\end{array}$ \\
\hline Control variables & yes & yes & yes & yes & yes \\
\hline $\begin{array}{l}N \\
\text { No. of municipalities }\end{array}$ & $\begin{array}{l}318 \\
159\end{array}$ & $\begin{array}{l}318 \\
159\end{array}$ & $\begin{array}{l}318 \\
159\end{array}$ & $\begin{array}{l}318 \\
159\end{array}$ & $\begin{array}{l}318 \\
159\end{array}$ \\
\hline
\end{tabular}

Sources: 2006 \& 2008, ISTAT; Telecom Italia.

Notes: Each panel B1-B3 shows coefficients from separate regressions. All estimations control for municipality fixed effects, year indicator, and a constant term. Robust standard errors in parentheses. All regressions include the same controls as in the main regressions except the one that is the respective dependent variable. 
Table 9. Placebo Analysis w.r.t. Population Share of High Educated

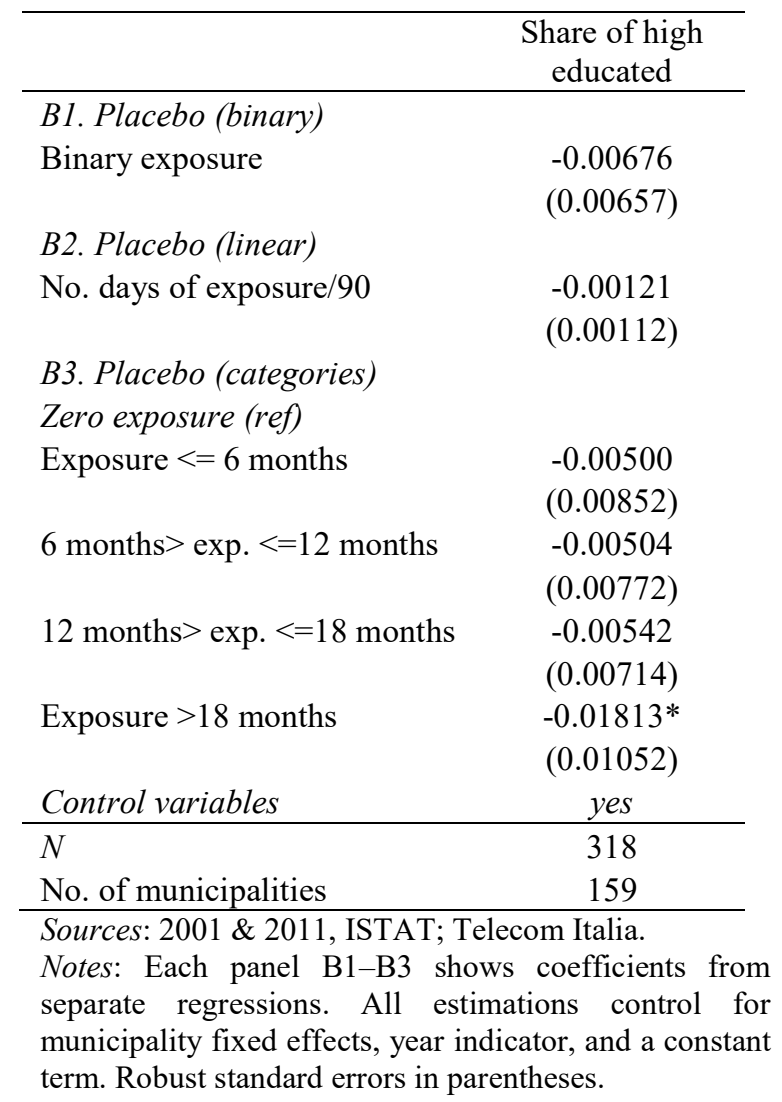


Table 10. Potential Mechanisms. Socioeconomic Municipality Characteristics

\begin{tabular}{|c|c|c|c|c|c|c|}
\hline & $\begin{array}{c}\text { Female } \\
\text { population } \\
\text { share }\end{array}$ & $\begin{array}{c}\text { Share of } \\
\text { population } \\
\text { aged } 18-65\end{array}$ & $\begin{array}{c}\text { Share of } \\
\text { population } \\
\text { aged more } \\
\text { than } 65\end{array}$ & $\begin{array}{l}\text { Share of net } \\
\text { migration }\end{array}$ & $\begin{array}{l}\text { Share of } \\
\text { foreigners }\end{array}$ & $\begin{array}{c}\text { Declared } \\
\text { personal } \\
\text { income, per } \\
\text { capita (log) }\end{array}$ \\
\hline & $(1)$ & $(2)$ & $(3)$ & $(4)$ & $(5)$ & $(6)$ \\
\hline \multicolumn{7}{|l|}{ A1. Baseline (binary) } \\
\hline Binary exposure & $\begin{array}{l}-0.0011 \\
(0.0031)\end{array}$ & $\begin{array}{c}0.0007 \\
(0.0046)\end{array}$ & $\begin{array}{c}0.0052 \\
(0.0056)\end{array}$ & $\begin{array}{l}-0.0014 \\
(0.0056)\end{array}$ & $\begin{array}{l}-0.0010 \\
(0.0042)\end{array}$ & $\begin{array}{l}-0.0108 \\
(0.0137)\end{array}$ \\
\hline \multicolumn{7}{|l|}{ A2. Baseline (linear) } \\
\hline No. days of exposure/90 & $\begin{array}{l}-0.0002 \\
(0.0004)\end{array}$ & $\begin{array}{l}-0.0007 \\
(0.0007)\end{array}$ & $\begin{array}{l}0.0010 * \\
(0.0006)\end{array}$ & $\begin{array}{l}-0.0007 \\
(0.0007)\end{array}$ & $\begin{array}{l}-0.0007 \\
(0.0005)\end{array}$ & $\begin{array}{c}0.0017 \\
(0.0022)\end{array}$ \\
\hline \multicolumn{7}{|l|}{ A3. Baseline (categories) } \\
\hline \multicolumn{7}{|l|}{ Zero exposure (ref) } \\
\hline Exposure $<=6$ months & $\begin{array}{c}0.0006 \\
(0.0034)\end{array}$ & $\begin{array}{c}0.0013 \\
(0.0055)\end{array}$ & $\begin{array}{l}-0.0014 \\
(0.0060)\end{array}$ & $\begin{array}{l}-0.0030 \\
(0.0062)\end{array}$ & $\begin{array}{c}0.0019 \\
(0.0050)\end{array}$ & $\begin{array}{l}-0.0123 \\
(0.0177)\end{array}$ \\
\hline 6 months $>$ exp. $<=12$ months & $\begin{array}{l}-0.0021 \\
(0.0034)\end{array}$ & $\begin{array}{c}0.0049 \\
(0.0056)\end{array}$ & $\begin{array}{c}0.0082 \\
(0.0059)\end{array}$ & $\begin{array}{c}0.0067 \\
(0.0063)\end{array}$ & $\begin{array}{l}-0.0023 \\
(0.0056)\end{array}$ & $\begin{array}{l}-0.0166 \\
(0.0158)\end{array}$ \\
\hline 12 months $>$ exp. $<=18$ months & $\begin{array}{l}-0.0018 \\
(0.0034)\end{array}$ & $\begin{array}{c}0.0005 \\
(0.0047)\end{array}$ & $\begin{array}{c}0.0068 \\
(0.0056)\end{array}$ & $\begin{array}{l}-0.0034 \\
(0.0058)\end{array}$ & $\begin{array}{c}0.0012 \\
(0.0045)\end{array}$ & $\begin{array}{l}-0.0106 \\
(0.0151)\end{array}$ \\
\hline Exposure $>18$ months & $\begin{array}{l}-0.0009 \\
(0.0038)\end{array}$ & $\begin{array}{l}-0.0063 \\
(0.0067)\end{array}$ & $\begin{array}{c}0.0054 \\
(0.0068)\end{array}$ & $\begin{array}{l}-0.0052 \\
(0.0072)\end{array}$ & $\begin{array}{c}-0.0097 * * \\
(0.0049)\end{array}$ & $\begin{array}{c}0.0006 \\
(0.0219)\end{array}$ \\
\hline Control variables & yes & yes & yes & yes & yes & yes \\
\hline$N$ & 318 & 318 & 318 & 318 & 318 & 318 \\
\hline No. of municipalities & 159 & 159 & 159 & 159 & 159 & 159 \\
\hline
\end{tabular}

Sources: 2008 \& 2013, Italian Ministry of Economy and Finance; ISTAT; Telecom Italia.

Notes: Each panel A1-A3 shows coefficients from separate regressions. All estimations control for municipality fixed effects, year indicator, and a constant term. Robust standard errors in parentheses. All regressions include the same controls as in the main regressions except the one that is the respective dependent variable. 
Table 11. Broadband Adoption-First-Stage Estimates

\begin{tabular}{lcc}
\hline & $\begin{array}{c}\text { Local ADSL } \\
\text { subscription rates }\end{array}$ & $\begin{array}{c}\text { Household } \\
\text { Internet access }\end{array}$ \\
\cline { 2 - 3 } A1. Baseline (binary) & $(1)$ & $(2)$ \\
Binary exposure & $0.18793^{* * *}$ & $0.13025^{*}$ \\
A2. Baseline (linear) & $(0.03340)$ & $(0.06662)$ \\
No. days of exposure/90 & $0.02707^{* * *}$ & 0.01469 \\
A3. Baseline (categories) & $(0.00451)$ & $(0.00966)$ \\
Zero exposure (ref) & & \\
Exposure $<=6$ months & $0.10947^{* *}$ & 0.11376 \\
6 months $>$ exp. $<=12$ months & $(0.04223)$ & $(0.08675)$ \\
& $0.18076^{* * *}$ & 0.08443 \\
12 months $>$ exp. $<=18$ months & $(0.03945)$ & $(0.08412)$ \\
Exposure $>18$ months & $0.21654 * * *$ & $0.15767 * *$ \\
& $(0.03373)$ & $(0.06894)$ \\
$N$ & $0.21122^{* * *}$ & $0.15133^{* *}$ \\
& $(0.04134)$ & $(0.07594)$ \\
\hline
\end{tabular}

Sources: (1) 2014, (2) 2008 \& 2013, Longitudinal Household Survey on Living Conditions in the Province of Trento; Telecom Italia.

Notes: ADSL2+ broadband availability refers to 24/02/2013. (1) Municipality-level data. The ADSL subscription rate is calculated for each municipality as the sum of $7 \mathrm{Mbps}$ and 20Mbps subscriptions of private households with Telecom Italia (as of March 1, 2014) multiplied by the average number of adults in households in municipalities addressed by the policy (2.2 in 2013), and divided by the number of eligible voters (as of February 24, 2013). Subscription data are not available for the municipalities of Fiera di Primiero, Imer, Mezzano, Siror, Tonadico, and Transacqua. (2) Household-level data, sampling-weight adjusted. Household fixed effects model with robust standard errors adjusted for clustering at municipality level. 
Table 12. Electoral Turnout-Two-Sample Two-Stage Least Squares (TSIV) Estimates

\begin{tabular}{|c|c|c|c|c|c|}
\hline & $\begin{array}{l}\text { Reduced form } \\
\text { (dep. var.: voter } \\
\text { turnout) }\end{array}$ & $\begin{array}{l}\text { First stage (dep. } \\
\text { var.: ADSL } \\
\text { subscription } \\
\text { rate) } \\
\end{array}$ & $\begin{array}{l}\text { First stage (dep. } \\
\text { var.: household } \\
\text { Internet access) }\end{array}$ & $\begin{array}{c}\text { TSIV } \\
\text { (based on } \\
\text { ADSL } \\
\text { subscription) } \\
\end{array}$ & $\begin{array}{c}\text { TSIV } \\
\text { (based on } \\
\text { household } \\
\text { Internet access) } \\
\end{array}$ \\
\hline & $(1)$ & $(2)$ & (3) & (4) & $(5)$ \\
\hline No. days of exposure/90 & $\begin{array}{l}0.00243^{*} \\
(0.00126)\end{array}$ & $\begin{array}{c}0.02707 * * * \\
(0.00451)\end{array}$ & $\begin{array}{c}0.01469 \\
(0.00966)\end{array}$ & $\begin{array}{l}0.08977^{*} \\
(0.04889)\end{array}$ & $\begin{array}{c}0.16542 \\
(0.13853)\end{array}$ \\
\hline$N$ & 318 & 153 & 1,154 & & \\
\hline Exposure $>18$ months & $\begin{array}{c}0.03253 * * \\
(0.01417)\end{array}$ & $\begin{array}{c}0.21122 * * * \\
(0.04134)\end{array}$ & $\begin{array}{c}0.15133 * * \\
(0.07594)\end{array}$ & $\begin{array}{c}0.15401 * * \\
(0.06717)\end{array}$ & $\begin{array}{c}0.21496 \\
(0.14284)\end{array}$ \\
\hline$N$ & 318 & 153 & 1,154 & & \\
\hline
\end{tabular}




\section{Appendix}

Table A1. Variable Description-Municipality Characteristics

\begin{tabular}{|c|c|}
\hline Variable & Description \\
\hline Demography & Source: ISTAT (2001) $14^{\circ}$ Censimento generale della popolazione e delle abitazioni \\
\hline Population density & Total no. of residents over municipal area (in square kilometers) \\
\hline Population growth rate, $10 \mathrm{yrs}$ & 10-year population growth rate (1991-2001) \\
\hline Employment rate & No. of employed residents over working age population (15-64) \\
\hline Population share high educated & No. of residents with upper secondary or higher education over total no. of residents \\
\hline Population share aged 65 and over & No. of residents aged at least 65 over total no. of residents \\
\hline Industry structure & Source: ISTAT (2001) $8^{\circ}$ Censimento dell'industria e dei servizi \\
\hline No. firms $(\log )$ & Total no. of firms \\
\hline Empl. growth rate, 10 yrs & 10-year growth rate of total no. of jobs (1991-2001) \\
\hline Empl. share in primary sector & No. of jobs in the primary sector (agriculture and mining) over total no. of jobs \\
\hline Empl. share in manufacturing & No. of jobs in manufacturing over total no. of jobs \\
\hline Empl. share in construction & No. of jobs in construction and utilities (gas, water, electricity) over total no. of jobs \\
\hline Empl. share in wholesale & No. of jobs in wholesale and retail over total no. of jobs \\
\hline Empl. share in services & No. of jobs in other services over total no. of jobs \\
\hline Geography & Source: ISTAT (2009) Atlante Statistico dei Comuni \\
\hline Municipality's altitude (log) & Altitude at the location of the city hall (in meters) \\
\hline Distance to nearest motorway $(\log )$ & Road distance of the municipality to the next motorway (in minutes) \\
\hline Previous ADSL technology & Source: Telecom Italia \\
\hline Pre-policy $7 \mathrm{Mbps}$ & Pre-policy availability of previous ADSL technology 7Mbps \\
\hline Pre-policy Lite & Pre-policy availability of previous ADSL technology Lite \\
\hline
\end{tabular}


Table A2. Party Classification (2006, 2008, and 2013)

\begin{tabular}{|c|c|c|}
\hline 2006 & 2008 & 2013 \\
\hline \multicolumn{3}{|c|}{ A. Left-fringe parties } \\
\hline Comunisti Italiani & Partito Comunista dei Lavoratori & Sinistra Ecologia Libertà \\
\hline Rifondazione Comunista & Sinistra Critica & Rivoluzione Civile \\
\hline di Pietro Italia dei Valori & La Sinistra L'Arcobaleno & \\
\hline \multirow[t]{2}{*}{ Federazione dei Verdi } & di Pietro Italia dei Valori & \\
\hline & Per il Bene comune & \\
\hline \multicolumn{3}{|c|}{ B. Established center-left parties } \\
\hline L'Ulivo & Partito Democratico & Partito Democratico \\
\hline La Rosa nel Pugno & Partito Socialista & \\
\hline \multicolumn{3}{|c|}{ C. Center and liberal parties } \\
\hline Unione di Centro & Unione di Centro & Scelta Civica con Monti per L'Italia \\
\hline \multirow[t]{2}{*}{ UDEUR Popolari } & Partito Liberale Italiano & Unione di Centro \\
\hline & & Fare per Fermare il Declino \\
\hline \multicolumn{3}{|c|}{ D. Established center-right parties } \\
\hline Forza Italia & Il Popolo della Libertà & Il Popolo della Libertà \\
\hline Alleanza Nazionale & Lega Nord & Lega Nord \\
\hline Lega Nord & & Mir - Moderati in Rivoluzione \\
\hline \multicolumn{3}{|l|}{$\begin{array}{c}\text { Democrazia Cristiana per le } \\
\text { Autonomie-Nuovo Psi }\end{array}$} \\
\hline \multicolumn{3}{|l|}{ Partito dei Pensionati } \\
\hline \multicolumn{3}{|c|}{ E. Right-fringe parties } \\
\hline Fiamma Tricolore & La Destra - Fiamma Tricolore & Casapound Italia \\
\hline Alternativa Sociale Mussolini & & La Destra \\
\hline \multicolumn{3}{|c|}{ E. Other and local parties } \\
\hline \multirow[t]{3}{*}{$\begin{array}{l}\text { Südtiroler Volkspartei } \\
\text { die Freiheitlichen }\end{array}$} & $\begin{array}{l}\text { Südtiroler Volkspartei } \\
\text { die Freiheitlichen }\end{array}$ & $\begin{array}{l}\text { Südtiroler Volkspartei } \\
\text { die Freiheitlichen }\end{array}$ \\
\hline & Union Für Südtirol & Movimento 5 Stelle \\
\hline & Unione Democratica per i Consumatori & \\
\hline
\end{tabular}


Table A3. Variable Description-Covariates

\begin{tabular}{ll}
\hline Variable & Description \\
\hline A. Electoral outcomes & Source: Italian Ministry of the Interior (elezionistorico.interno.it) \\
Turnout & Number of total votes (valid or invalid) on eligible voters \\
Invalid vote & Number of invalid votes (null and white votes) on eligible voters \\
Party vote share & Share of votes for a party group on valid votes \\
B. ADSL2+ broadband & Source: Telecom Italia \\
Days of exposure & Days of broadband availability evaluated at the respective date of election \\
C. Demographic characteristics & Source: Italian National Institute of Statistics (ISTAT) (demo.istat.it, intercensal estimates) \\
Population size & Resident population \\
Population share female & Share of females among resident population \\
Population share aged 18-65 & Share of individuals aged 18-65 among resident population \\
Population share aged 65 and over & Share of individuals aged 65 and over among resident population \\
Net migration rate & Difference between in- and out-migration over resident population \\
Share of foreigners & Share of individuals with foreign citizenship among resident population \\
D. Economic characteristics & Source: Italian Ministry of Economy and Finance (www.finanze.gov.it) \\
Per-capita declared personal income & Per-capita tax base, personal income taxes \\
\hline
\end{tabular}

